Sakarya Üniversitesi İlahiyat Fakültesi Dergisi

Journal of Sakarya University Faculty of Theology

ISSN: 2146-9806 | e-ISSN: 1304-6535

Cilt/Volume: 22, Sayı/Issue: 42, Y11/Year: 2020 (Aralık/December)

\title{
Katılım Bankacılığında Kullanılan Yatırım Vekaleti Hesaplarının Fıkhi ve İktisadi Tahlili
}

Islamic Jurisprudence and Economic Analysis of the Wakāla Investment Accounts in Participation Banking

\author{
Mücahit Özdemir \\ Arş. Gör. Dr., Sakarya Üniversitesi İslam Ekonomisi ve Finansı Uygulama ve Araştırma \\ Merkezi - Res. Asst. Dr., Sakarya University Research Center for Islamic Economics and \\ Finance (RECISEF) \\ mucahitozdemir@sakarya.edu.tr \\ https://orcid.org/0000-0002-4455-5943
}

\begin{abstract}
Nazan Lila
Arş. Gör., Sakarya Üniversitesi İslam Ekonomisi ve Finansı Uygulama ve Araştırma Merkezi - Res. Asst., Sakarya University Research Center for Islamic Economics and Finance (RECISEF) nazankapici@sakarya.edu.tr https://orcid.org/0000-0003-4858-233X
\end{abstract}

\section{Makale Bilgisi - Article Information}

Makale Türü/Article Type: Araştırma Makalesi/ Research Article

Geliş Tarihi/Date Received: 16/07/2020

Kabul Tarihi/Date Accepted: 16/11/2020

Yayın Tarihi/Date Published: 15/12/2020

Atıf/Citation: Özdemir, Mücahit - Lila, Nazan. “Katılım Bankacılığında Kullanılan Yatırım Vekaleti Hesaplarının Fıkhi ve İktisadi Tahlili". Sakarya Üniversitesi İlahiyat Fakültesi Dergisi 22/42 (2020), 343-372. https://doi.org/10.17335/sakaifd.769835.

İntihal: Bu makale, iThenticate yazılımı ile taranmış ve intihal tespit edilmemiştir. Plagiarism: This article has been scanned by iThenticate and no plagiarism detected.

Copyright $\odot$ Published by Sakarya Üniversitesi İlahiyat Fakültesi - Sakarya University Faculty of Theology, Sakarya/Turkey. 


\title{
Katılım Bankacılığında Kullanılan Yatırım Vekaleti Hesaplarının Fıkhi ve İktisadi Tahlili
}

\section{Öz}

Katılım bankaları Türkiye'de tasarrufların kâr zarar paylaşımına göre değerlendirilmesini sağlayan en önemli kurumların başında gelmektedir. Ancak 2018 yılındaki düzenleme ile bu kurumlar kâr zarar paylaşımının yanında vekalete dayalı olarak da fon toplamaya başlamış ve bu durum eleştirileri beraberinde getirmiştir. Yatırım vekaleti hesaplarında fıkhi açılardan çeşitli sakıncalar bulunmakta ve katılım bankacılığının özgün tarafı olan kâr zarar paylaşımı esasından uzaklaşılmasına kapı aralayacağı endişesi doğmaktadır. Bu çalışmanın temel amacını, katılım bankalarındaki yatırım vekaleti hesaplarının işleyiş̧ini fıkhi yönlerinin yanında piyasa dinamikleri açısından da ele almak ve böylece konuyu farklı boyutlardan tartışarak anlaşılmasını sağlamak oluşturmaktadır. Çalışmada katılım bankalarının halka açık güncel verileri ve dokümanlarından istifade edilmiştir. Yapılan araştırma sonucunda yatırım vekaleti hesaplarının klasik fıkıhtan ayrılan, başta tahmini kâr olmak üzere çeşitli sorunlu kısımlarının olduğu ortaya konulmuştur. Diğer yandan kâr zarar katılma hesaplarıyla birlikte katılım bankacılığına yatırım vekaleti hesaplarının dahil edilmesinin gerekçesini oluşturan, getiri hassasiyeti yüksek müşterilerin katılım bankasında tutulabilmesi anlayışının arizi bir durumdan kaynaklandığı ve bu gerekçenin böylesine yapısal bir değişikliğe neden olmasının sektörün özgünlüğünden tavizler vermesine yol açabileceği sonucuna ulaşılmıştır.

Anahtar Kelimler: Katılım Bankacılığı, İslami Finans, Vekalet, Yatırım Vekaleti Hesapları, Katılma Hesapları, Tahmini Kâr.

\section{Islamic Jurisprudence and Economic Analysis of the Wakāla Investment Accounts in Participation Banking}

\begin{abstract}
Participation banks that evaluate the savings according to the profit-loss sharing (PLS) principle are one of the essential institutions in Turkey. However, with the regulation in 2018, these institutions started to collect funds based on wakāla (agency) accounts, in addition to PLS, and this brought criticisms. There are various drawbacks in terms of the Islamic jurisdiction (figh) in wakāla investment accounts, and there is a concern that it might open the door to diverge from the PLS principle, which is the authentic side of participation banking. The main purpose of this study is to address the functioning of wakāla investment accounts in participation banks in terms of market dynamics as well as their figh aspects and thus to understand the issue from different dimensions. In the study, disclosed data and documents of participation banks are used. As a result of the research, it has been revealed that the wakāla investment accounts have various problematic parts that differ from classical fiqh, especially the expected profit ratio. On the other hand, it was concluded that the rationalisation for the introduction of wakāla investment accounts together along with the PLS accounts motivation is to keep high return, sensitive customers within the participation bank, which was raised by a temporary situation. So, that reason may cause divergence from the authenticity of the participation sector.

[You may find an extended abstract of this article after the bibliography.]

Keywords: Participation Banking, Islamic Finance, Wakāla, Wakāla Investment Accounts, Participation Accounts, Expected Profit.

\section{Giriş}

İslami finans, sözleşmeler bütünüdür. Diğer bir ifade ile yapılan her işlem İslami açından uygun bulunan bir ya da birden fazla sözleşme üzerine bina edilmekte ve müşterilere sunulan ürünler buna göre yapılandırılmaktadır. Vekalet de bu sözleşmelerden biridir ve İslami finansın farklı alanlarında son
\end{abstract}


dönemde yoğun şekilde kullanılmaya başlanmıştır. Dünya İslami finans piyasasında görülen bu eğilim Türkiye için de söz konusudur. Halihazırda uzun yıllar boyunca vekalet bir yan sözleşme olarak özellikle murabaha (maliyet + kârlı vadeli satış) işlemlerinde malın katılım bankası adına müşteri tarafından alınması sürecinde tercih edilmiş ve genelde bu tarz ürünlerin temelini oluşturmak yerine süreçlerin yürütülmesinde tamamlayıcı sözleşme olarak kullanılmıştır. Bu nedenle katılım bankacılığı işlemlerinde vekalet çok dikkat çekici bir enstrüman olarak ele alınmamıştır. Bununla birlikte katılım bankalarının en önemli fonksiyonlarından olan İslami yollarla fon toplama ve yatırımcılara kâr zarar ortaklığına göre getiri sağlamak için mudârebe hesapları kullanılırken, son dönemde bu hesapların yanında yatırım vekaleti hesapları bir fon toplama ürünü olarak sunulmuştur. Buna göre katılım bankası fon sahiplerinden yatırımlarda değerlendirmek amacıyla fonları vekalet akdine göre toplamaktadır. Böylece vekalet bir yan sözleşme olmasının yanında katılım bankalarının en temel işlevlerinden biri olan fon toplama kısmında, üzerine müstakil bir ürünün bina edildiği bir sözleşmeye dönüşmüştür.

2018 yılında yapılan düzenleme ${ }^{1}$ ile katılım bankalarının yatırım vekaletine dayalı olarak fon toplamalarının önü açılmıştır. Kuruldukları günden bu yana mudârebe esasına göre fon toplarken katılım bankalarının ilk defa vekalete dayalı bir ürünü de sunmaları oldukça dikkat çekici bir durumdur. Neden böyle bir kırılmanın yaşandığının uygulama açısından piyasa dinamikleri içerisinde ele alınması gerekmektedir. Bununla birlikte müşterilerle tahmini sabit bir kâr oranı üzerinde anlaşma yapılması gibi bazı meseleler fıkhi açıdan tartışmaları beraberinde getirmektedir. Özellikle faizli işlemlerle benzerlik taşıma tehlikesi barındıran ya da böyle bir algıya sebep olabilecek vekalete dayalı katılma hesaplarının fıkhi açıdan incelenmesi ve anlaşılması büyük önem taşımaktadır. Çünkü katılım bankalarının en temel özelliği faizsiz olmalarıdır. Bu faizsizlik finansman tarafında olduğu kadar fon toplama tarafında da aynı derecede önemlidir. Vekalet hesaplarına yönelik düzenlemelerin ilk çıktığı günlerde verilen tepkiler bu hesapların daha yakından incelenmesi ve dünya uygulamaları çerçevesinde ele alınmasını gerekli kılmaktadır. Aksi halde bu hesapların düzenleme ile önünün açılması "katılım bankacılığının köküne kibrit suyu dökülmüş” 2 şeklinde tepkilere neden olabilmektedir. Bu tarz bir yaklaşıma verilen cevapların da çok kapsamlı ve açıklayıcı olmadığı söylenebilir.

1 Mevduat ve Katılım Fonunun Kabulüne, Çekilmesine ve Zamanaşımına Uğrayan Mevduat, Katılım Fonu, Emanet ve Alacaklara İlişkin Usul ve Esaslar Hakkında Yönetmelik, Resmî Gazete 30569 (18 Ekim 2018).

2 İslam İktisadı Araştırmaları Vakfı (IKTISSAT), “Katılım Bankacılı̆̆ının Ruhuna el-Fatiha mı?” (Erişim 18 Nisan 2020). 
Bu çerçevede çalışmanın temel amacını, katılım bankalarının vekalete dayalı hesaplarının işleyişini fıkhi yönlerinin yanında piyasa dinamikleri açısından da ele almak ve böylece konuyu farklı boyutlardan tartışıp anlaşılmasını sağlamak oluşturmaktadır. Bugüne kadar İslami finansta vekaletin kullanımına yönelik az sayıda çalışma yapılmıştır. Bu çalışmaların büyük kısmı konuyu fıkhi boyutu üzerinden ele almış, uygulama açısından sınırlı bir şekilde değerlendirmiştir. İsmail Halitoğlu, çalışmasında İslami bankalardaki mudârebe hesapları ile yatırım vekaleti hesaplarının fıkhi yönlerini tahlil etmiştir. Bu bağlamda yatırım vekaletinde vekil konumundaki bankanın müşteriye karşı üstlendiği yükümlülükleri, İslam'daki akit teorisi çerçevesinde değerlendirmiştir. ${ }^{3}$ Diğer yandan Mustafa Çakır, yatırım vekaletinde kârın tazmini problemini müşteri ve katılım bankası açısından incelemiştir. Vekalet sözleşmesinin fikhen geçerli olabilmesi için kâr tazmininin açıkça şart koşulmaması ve bu uygulamanın teamül haline gelmemesi gerektiğini belirtmiştir. ${ }^{4}$

Fıkhi olarak vekalete dayalı hesapları inceleyen bu çalışmaların yanında, Muhammet Kürşat Öztürk hazırladığı doktora tezinde uygulama perspektifinden konuyu değerlendirmiş ve Türkiye'deki katılım bankalarına model önerisinde bulunmuştur. Modelde, risk seviyeleri belirlenmiş alternatif projeler özelinde havuzların oluşturulmasını ve sonrasında bu proje havuzlarının finansmanı için vekalet hesapları yoluyla fonların toplanmasını önermiş, bu şekilde şeffaflık ile etkinliğin artırılabileceğini ileri sürmüştür. Diğer yandan, araştırmasında dünya örneklerinden de bahsederek vekaleti kapsamlı bir şekilde açıklamış, ancak konuyu 2018 yılındaki mevzuat çerçevesinde hem piyasa dinamikleri hem de fikhi açllardan dar bir çerçevede incelemiştir. ${ }^{5}$

Bu çalışma hem vekaletin dünyadaki İslami bankacılıkta uygulanışını hem de Türkiye' de genelde vekaletle fon toplama işlemini, özelde ise vekalete dayalı katılma hesaplarını farklı açılardan inceleyip öneriler sunması açısından özgünlük taşımaktadır. Literatürde çok fazla üzerinden durulmayan İslami bankacılıkta vekaletin kullanımı ile ilgili akademik çalışmalara katkı sunması ve sektöre yönelik çok temel bir ürün geliştirme sürecini incelemesi açısından da politika yapıcılara bundan sonraki benzer süreçlerde bir fikir vermesi umulmaktadır. Ayrıca vekaletle ilgili fıkhi meselelerin derinlemesine analizi, konunun sağlam bir zemine oturtulması ve uygulamanın eksik ve problemli

3 İsmail Halitoğlu, "Yatırım Araçlarının Fıkhi Niteliği”, Kilis 7 Aralık Üniversitesi İlahiyat Fakültesi Dergisi 5/8 (2018), 139-163.

4 Mustafa Çakır, "Yatırım Vekâleti Uygulamalarında Kârın Tazmini Problemi", Marife Dini Araştırmalar Dergisi 19/1 (2019), 23-44.

5 Muhammet Kürşat Öztürk, Vekalet Yönteminin İslami Finanstaki Yeri ve Türkiye İçin Bir Model Önerisi (İstanbul: İstanbul Sebahattin Zaim Üniversitesi, Sosyal Bilimler Enstitüsü, Doktora Tezi, 2019). 
yönlerinin ıslah edilerek devam ettirilmesi yönünde atılacak adımlara ışık tutacaktır.

Çalışmada ilk olarak İslam hukukuna göre vekaletin tanımı ve taşıdı̆̆ı unsurlar mevcut teorik çalışmalar üzerinden ele alınmaktadır. İkinci bölümde konunun uygulama sahasını oluşturan İslami bankacılıkta vekaletin kullanım alanları dünya örnekleri üzerinden incelenmektedir. Sonrasında Türkiye'de vekalete dayalı fon toplama yöntemleri katılım bankalarının halka açık güncel verileri ve mevcut dokümanlar (faaliyet raporları, yasal düzenlemeler, vb.) kullanılarak açıklanmaktadır. Türkiye'deki uygulamaların incelenmesi sonrasında vekalete dayalı katılma hesapları fikhi ve uygulama perspektiflerinden tartışılmaktadır. Son olarak ise öneriler sunularak çalışma neticelendirilmektedir.

\section{Vekaletin F1khi Boyutu}

Vekalet akdi, İslam hukukunda tasarruf yetkisini vekile devretmek anlamina gelmektedir. ${ }^{6}$ Vekalet akdinin meşruiyeti, Hz. Peygamber (sav)'in Hakim b. Hizam adlı sahabeyi kurbanlık hayvan alımı konusunda vekil tayin etmesi gibi rivayetler 1şı̆̆ında sünnete ve fıkıh alimlerinin konuyla ilgili görüş birliğine varması sebebiyle icma deliline dayandırılmaktadır. Ayrıca herkesin kendi işini bizzat yapma imkanına sahip olmamasından dolayı işlerin vekalet yoluyla yaptırılması, ihtiyaca binaen gerekli bir husus olarak görülmüştür. ${ }^{7}$

Vekalet akdi, tarafların karşılıklı irade beyanlarıyla kurulur. Burada akdi yapan tarafların, hukuki işlem yetkisi veren eda ehliyetine (pozitif hukukta fiil ehliyeti) sahip olmaları gerekmektedir. Vekalete konu olan iş, öncelikle müvekkilin yetkisi dahilinde olmalıdır. Ayrıca vekilin işlemi yerine getirmesini imkânsız kılacak derecedeki bilinmezlik, akdin kurulmasını engeller. ${ }^{8}$ Hanefi mezhebine göre vekalet akdinin kurucu unsuru, karşılıklı irade beyanıdır. ${ }^{9}$ Kurucu unsurla ilgili vazgeçilmez vasıf ve şartlar da vekalet akdinin kuruluş (in'ikad) şartlarıdır. Kuruluş şartlarından biri akitte bulunmadığı zaman vekalet hükümsüz (batıl) kabul edilir. Akdin geçerlilik (sıhhat) şartları ise akitte belirsizlik, hata ve aldanma ihtimalinin bulunmaması, şartların örfe ve akdin gereğine aykırı olmaması ve taraflardan birine ek fayda sağlamaması gibi hususlardır. Ayrıca vekalette ücret almak caizdir. ${ }^{10}$

6 Alâuddin Kâsânî, Bedâi'u's-sanâi' fì tertîbi'ş-şerâi' (Beyrut: Dâru'l-Kütübi'l-i̇lmiyye, 2003), 426.

7 Burhâneddin Merğınânî, el-Hidâye fì şerhi Bidâyetü'l-mübtedî̀ (Pakistan: İdâretü'l-Kur'an ve'lUlûmü'l-İslâmiyye, 1996), 484-485.

8 Ali Haydar Arsebük, Düreru'l-hukkâm şerhu Mecelleti'l-ahkâm (Beyrut: Dâru Âlemi'l-Kütüb, 2003), 521.

9 Bilal Aybakan, İslam Hukukunda Vekalet Sözleşmesi (İstanbul: Marmara Üniversitesi, Sosyal Bilimler Enstitüsü, Yüksek Lisans Tezi, 1990), 19.

10 Bilal Aybakan, "Vekalet", Türkiye Diyanet Vakfi İslam Ansiklopedisi (Ankara: Türkiye Diyanet Vakfı Yayınları, 2013), 43/1-6. 
Vekalet akdi, iki tarafa da ifa sorumluluğu yükleyen bir akittir. Bununla beraber, vekalette asıl sorumluluğu vekil üstlenir. Vekilin yetki sınırları, vekaletin sınırlı veya mutlak olmasına göre değişiklik göstermektedir. Müvekkilin, vekilin yürüteceği işi belirli açılardan sınırlandırması durumunda sınırlı (mukayyed) vekalet söz konusudur. Müvekkilin, yürütülecek iş konusunda herhangi bir sınırlandırma yapmaması durumunda ise sınırsız (mutlak) vekalet söz konusudur. ${ }^{11}$ Sınırlı vekalette vekil, işi örfe riayet ederek yürütme yanında müvekkilin akitte getirdiği sınırlamalara da bağlı kalmak zorundadır. Mutlak vekalette ise vekilin yetki sınırlarını, yapılacak işin niteliği ile bu konudaki hukuki örf ve uygulama belirler. ${ }^{12}$

Vekalette vekilin borcu temelde müvekkil tarafından yüklenen işi, müvekkilin iradesine ve yararına uygun şekilde ve zamanında ifa etmektir. Müvekkilin iradesi akit anındaki beyanından anlaşılır. Müvekkilin akit anında özel bir beyanı bulunmadığı takdirde vekil, işin yürütülmesinde örfe riayet eder. ${ }^{13}$ Ayrıca işin bitiminde vekil, elinde bulunan müvekkile ait malları teslim etmek zorundadır. Burada malların -ve varsa elde edilen kazancın- mülkiyeti her durumda müvekkile aittir. ${ }^{14}$

Vekalette müvekkilin borçları kapsamında sayılabilecek hususlardan biri, vekilin ücretinin ödenmesidir. Vekalet akdi ücretli ise vekil, ifayı yerine getirmesi neticesinde ücrete hak kazanır. Başlangıçta ücret belirlenmemişse ve vekilin ücret alacağ 1 biliniyorsa vekil, emsal ücrete hak kazanır. ${ }^{15}$ Buna ilave olarak vekil, ifayı yerine getirirken yaptığı zorunlu masrafları müvekkilden tahsil eder. ${ }^{16}$ Ayrıca işin görülmesi sırasında vekilin elindeki mal, emanet hükmündedir. Kasıt, kusur veya ihmali olmadığı halde vekilin elindeki mal kısmen veya tamamen hasara uğramışsa bu hasarı vekilin tazmin etmesi gerekmez. ${ }^{17}$

\section{Vekaletin İslami Bankacılıkta Kullanım Alanları}

Uluslararası literatürde wakāla (agency) şeklinde ifade bulan vekalet sözleşmeleri İslami bankacılıkta özellikle fon toplama tarafında sıklıkla kullanılmaktadır. Ortadoğu ve Kuzey Afrika bölgesinde vekalete dayalı hesaplar halihazırda yaygınken Malezya' da da gittikçe popüler hale geldiği ifade edilmektedir. ${ }^{18}$ Hem bireysel/ticari müşterilerden vekalete dayalı hesaplar açılarak fon

11 Alâuddin Semerkandî, Tuhfetü'l-fukahâ (Beyrut: Dâru'l-Kütübi'l-İlmiyye, 1984), 232.

12 Arsebük, Düreru'l-hukkâm, 515.

13 Ebû İshak Şîrâzî, el-Mühezzeb fi fikhi'l-İmâm eş-Şâfi î (Dımaşk: Dâru'l-Kalem, 1992), 351.

14 Aybakan, İslam Hukukunda Vekalet Sözleşmesi, 53.

15 Arsebük, Düreru'l-hukkâm, 573-574.

16 Aybakan, İslam Hukukunda Vekalet Sözleşmesi, 67.

17 Arsebük, Düreru'l-hukkâm, 561.

18 İslam İşbirliği Teşkilatı Ekonomik ve Ticari İşbirliği Daimi Komitesi (İSEDAK), Diversification of Islamic Financial Instruments (Ankara: ISEDAK Koordinasyon Ofisi, 2017), 16. 
kabul edilebilmekte hem de uluslararası piyasalardaki yatırımcılardan kısa vadeli olarak vekaletle kaynak temin edilebilmektedir. Burada İslami bankanın bir aracı olarak fonları yönetmesi söz konusudur. Yapılan sözleşmeye göre İslami banka, vekalet veren kişi/kurum adına fonu değerlendirmekte, sonucun menfi ya da müspet olmasından bağımsız olarak vekalet ücreti almaktadır. Sözleşmede belirtilen kurallar çerçevesinde yatırımların yönetilmesi İslami bankanın sorumluluğundadır ve sözleşmeden doğan sorumluluklarını yerine getirirken gerekli hassasiyeti ve özeni göstermesi gerekmektedir.

Şekil 1: Islami bankacılıkta vekalete dayalı yatırım hesaplarının genel işleyişi

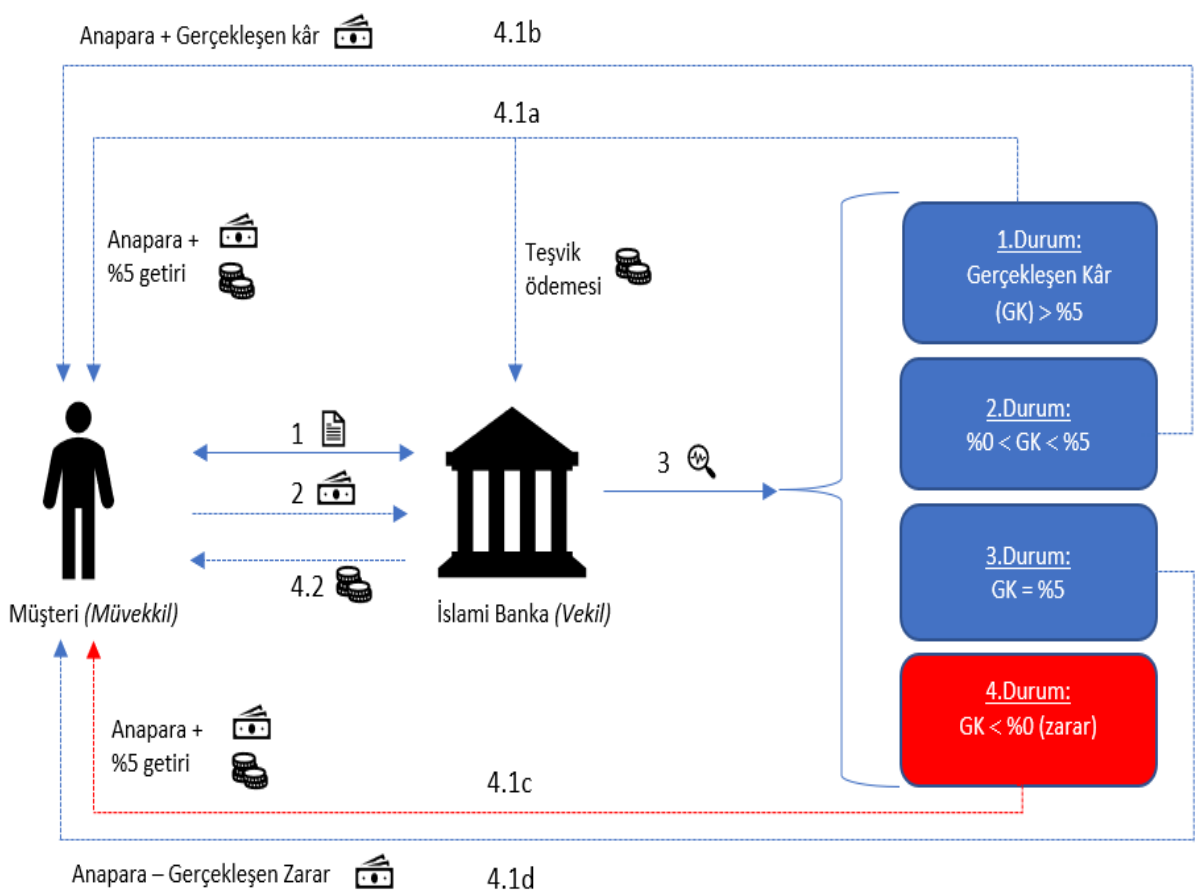

Not: İslami banka ve müşteri arasında \%5 beklenen kâr üzerinden anlaşıldı̆̆ 1 varsayımıyla hazırlanmıştır.

Vekalete dayalı yatırım hesaplarının işleyişi Şekil 1'de sunulmuştur. Buna göre İslami bankaların kendilerine özgü bazı farklılıkları olabilmekle birlikte teorik olarak süreç şu adımlardan oluşmaktadır:

1. Müşteri (müvekkil), İslami bankada (vekil) vekalet yatırım hesabı açar ve \%5 beklenen kâr üzerinde anlaşırlar.

2. Müşteri parasını şer'î uyumlu yatırımlarda kullanması için İslami bankaya vekalet hesabı üzerinden yatırır.

3. İslami banka vekil sıfatıyla müşteri adına, yatırılan parayı İslami açıdan uygun finansman faaliyetlerinde değerlendirir.

4.1. Faaliyetler sonucunda dört ihtimal söz konusudur; 
4.1a. Gerçekleşen Kâr (GK) > \%5 : İslami banka müşteriye anapara ve \%5'lik kârı öder, geri kalan (\%7 GK örneği üzerinden) \%2'lik kâr ise İslami bankaya sözleşmede anlaşılan şekilde teşvik primi olarak kalır.

4.1b. \%0 < GK < \%5 : İslami banka ne kadar kâr gerçeklemişse (Örneğin \%3) anapara ile birlikte bu kârı müşteriye öder.

4.1c. GK < \%0 : İslami banka yaptı̆̆ yatırımlardan zarar etmişse anaparadan kalan tutar müşteriye ödenir.

4.1d.GK = \%5 : Yapılan anlaşma sonucu üzerinde anlaşılan beklenen kâr kadar yatırımlardan bir kâr elde edilmişse İslami banka anapara ve \%5 kârı müşterisine öder.

4.2. İslami banka vekil sıfatı ile üzerinde anlaştıkları vekalet ücretini müşterisinden tahsil eder. Uygulamada genellikle bu vekalet ücreti, vekalet yatırım hesabının vadesi sonunda müşteriye ödenecek olan tutardan (anapara +/- kâr/zarar) düşülmektedir.

İslami bankalarda yatırım vekaleti hesapları açılabilmesi için minimum yatırılması gereken tutar, vade ve hedef müşteri segmenti farklılık gösterebilmektedir. Örneğin, dünyanın en büyük İslami bankalarından olan Birleşik Arap Emirlikleri'ndeki (BAE) Emirates NBD'de vekalet yatırım hesabı açabilmesi için bireysel ya da kurumsal müşterilerin minimum 1 milyon USD (4 milyon AED) yatırması gerekmektedir. ${ }^{19}$ Benzer şekilde Nijerya' nın ilk İslami bankası olan Jaiz Bank da "alacakları riskle orantılı şekilde yüksek getiri bekleyen şirketlere ve yüksek gelire sahip bireylere" bu hesabı açtıklarını ifade etmektedir. ${ }^{20} \mathrm{Bu}$ nedenle minimum tutarı 300 milyon naira (yaklaşı 800 bin USD) olarak tayin etmişlerdir. Bu örneklerden farklı olarak Bahreyn'de faaliyet gösteren Kuwait Finance House (KFH) grubuna ait KFH Bahrain, vekalet yatırım hesaplarında diğerlerine göre çok daha düşük bir rakam olarak 1.000 Bahreyn dinarı (10.000 USD) belirlemiştir. ${ }^{21}$ Tüm uygulamalarda beklenen (expected) getiri tarafların kendi aralarındaki anlaşmaya göre belirlenmektedir. Burada önemli olan kriterlerden biri mudârebeye dayalı yatırım hesaplarında olduğu gibi hesabın vadesidir. Genellikle vadeler -örneğin Emirates NBD- 1, 3, 6, 9 ve 12 ay olarak belirlenirken bazı İslami bankalarda -örneğin KFH Bahrain- 1, 3, 5 yıla kadar da çıkabilmektedir. Diğer yandan İslami bankalarda vekalete dayalı hesaplar çoğunlukla getiri beklentisi yüksek olan müşteri gruplarındakileri çekmek amacı taşımakta ve bunların yanında mudârebeye yatırım hesapları da tüm müşteriler için sunulmaya devam etmektedir. Vekaletin basit yapısı ve esnekliği İslami bankalar ve müşteriler için çift taraflı bir şekilde cazip gelmektedir.

19 Emirates NBD, “Wakala Deposits" (Erişim 6 Nisan 2020).

20 Jaiz Bank Plc, “Jaiz Wakala Investment” (Erişim 6 Nisan 2020).

21 KFH Bahrain, “'Wakala' Investment Account” (Erişim 6 Nisan 2020). 
İslami bankalar müşterilerinden fon toplama amacıyla vekalet yatırım hesapları oluşturabilirken diğer taraftan yine vekalet üzerinden uluslararası bankacilık faaliyetleri ile de kurumsal yatırımcılardan fon temin edebilmektedirler. Özellikle İslami bankaların birbirleri arasındaki işlemleri seviyesinde vekalet üzerinden yapılan anlaşmalar ile âtıl kalan likidite kısa dönemli olarak diğer İslami banka (vekil) tarafından değerlendirilmekte ve bu şekilde getiri sağlanmaktadır. İslami bankalar arasındaki işlemlerde vekaletin kullanılması, sektör açısından oldukça eleştirilen bir uygulama olan teverruke dayalı commodity murabaha işlemi yerine vekaletle fonların değerlendirilmesinin önünü açmıştır. ${ }^{22}$

Tüm bunlarla birlikte İslami bankaların fon temin etme ürünlerinde vekaletle ilgili bazı problemler de söz konusudur. Bunlardan en önemlisi vekalet problemi (agency problemi)dir. Diğer bir ifade ile müvekkilin sermayesinin vekil tarafından gereken özveri ile kullanılıp kullanılmadı̆̆ıdır. Burada bir çıkar çatışması söz konusu olabilir. Böyle bir durumda müvekkil vekili kendi çıkarına uygun yatırımlarda bulunmadığı şeklinde töhmet altında bırakacak şekilde suçlayabilir. ${ }^{23}$ Bununla birlikte aynı durum mudarebeye dayalı hesaplar için de geçerli olabilir; ancak İslami bankaların kurumsal yapıları ve müşteri memnuniyetini önceleyen yapıları bu tarz bir suçlama durumunu bir nebze de olsa azaltmaktadır.

\section{Katılım Bankalarında Vekaletin Fon Toplamada Kullanıldığı Alanlar}

Dünyadaki uygulamalara benzer olarak Türkiye'de de katılım bankaları vekalet sözleşmelerini fon toplama konusunda son yıllarda yaygın şekilde kullanmaktadır. 2018 yılı öncesine kadar vekalet, uluslararası bankacılık sözleşmelerinde tercih edilmekteyken bu tarihten itibaren daha geniş bir kesime yurt içinde sunulmuştur.

\subsection{Katılım Bankalarının Uluslararası Bankacılık Alanında Vekaleti Kul- lanımı}

Katılım bankaları vekalet sözleşmeleri ile başta körfez ülkeleri olmak üzere faizsiz bankalarda biriken âtıl fonları değerlendirmektedir. Yapılan sözleşmeye göre karşı tarafa belirli bir getiri tahmini sunulmaktadır ve bu oranın kesin olarak ödenmesi diye bir şart bulunmamaktadır. Paranın faizsizlik prensiplerine uygun bir şekilde değerlendirilmesi sonucunda elde edilen kâr,

22 Reuters UK, “Islamic Banks Launch Standard Wakala Agreement, Eye Uniformity” (Erişim 6 Nisan 2020).

23 Abdul Ghafar Ismail vd., "Tawarruq Time Deposit with Wakalah Principle: An Option That Triggers New Issues", International Journal of Islamic and Middle Eastern Finance and Management 9/3 (2016), 388-396. 
belirlenen oranın üzerine çıkarsa artan tutar katılım bankasında bir teşvik olarak kalmaktadır24. Yurt dışındaki İslami bankalar ya da kurumlardan vekalet yoluyla temin edilen fonlar genellikle kısa vadelidir. ${ }^{25}$

Tablo 1: Katılım Bankalarının Aldı ̆̆ Vekalet Kredileri²6 (Milyon TL)

\begin{tabular}{|llllllllll|}
\hline & $\mathbf{2 0 1 1}$ & $\mathbf{2 0 1 2}$ & $\mathbf{2 0 1 3}$ & $\mathbf{2 0 1 4}$ & $\mathbf{2 0 1 5}$ & $\mathbf{2 0 1 6}$ & $\mathbf{2 0 1 7}$ & $\mathbf{2 0 1 8}$ & $\mathbf{2 0 1 9}$ \\
\hline $\begin{array}{l}\text { Albaraka } \\
\text { Türk }\end{array}$ & 416 & 578 & 1.055 & 1.165 & 821 & 787 & 1.802 & VY & 978 \\
\hline $\begin{array}{l}\text { Kuveyt } \\
\text { Türk }\end{array}$ & 391 & 1.014 & 1.525 & 1.665 & 1.824 & 2.241 & 2.701 & VY & 0 \\
\hline $\begin{array}{l}\text { Türkiye } \\
\text { Finans }\end{array}$ & 55 & 175 & 388 & 499 & 219 & 86 & 62 & VY & 0 \\
\hline $\begin{array}{l}\text { Ziraat } \\
\text { Katılım }\end{array}$ & - & - & - & - & - & 71 & 118 & VY & 53 \\
\hline $\begin{array}{l}\text { Vakıf } \\
\text { Katılım }\end{array}$ & - & - & - & - & - & 0 & 121 & VY & 286 \\
\hline Toplam & 862 & 1.767 & 2.968 & 3.329 & 2.865 & 3.184 & 4.804 & 0 & 1.317 \\
\hline
\end{tabular}

Kaynak: TKBB Veri Seti, https://www.tkbb.org.tr/veri-seti, erişim tarihi: 18.04.2020. "Katılım Fonu Harici Kaynaklar" kategorisinde "Wakale Kredileri" kaleminden derlenmiştir. Not: Sitede, 2018 yılına ilişkin herhangi bir veri paylaşılmamıştır. Bu nedenle Veri Yok (VY) olarak belirtilmiştir. Yılsonu verileri için "IV. Dönem" rakamları alınmıştır.

24 Kuwait Finance House (KFH), “Wakalah Account” (Erişim 12 Kasım 2020).

25 Kenan Dede, Katılım Bankalarında Hazine Ürünleri ve Sermaye Piyasası Uygulamaları (İstanbul: TKBB Yayınları, 2017), 106.

26 TKBB tarafından sunulan verilerde uluslararası kuruluşlardan vekalet yolu ile temin edilen fonlar için "wakala kredileri" ismi kullanılmaktadır. Bu ifadedeki wakala sözcüğü tarafımızdan vekalet olarak değiştirilmiş ve başlıkta bu şekilde sunulmuştur. Bununla birlikte uluslararası piyasalardan vekalet yoluyla elde edilen fonlar için katılım bankalarının farklı isimlendirmeleri mevcuttur. En fazla tutarda ve uzun süreli olarak bu fonlara başvuran katılım bankalarından biri olan Albaraka Türk Katılım Bankası ilk yıllarda "yatırıma esas wakala sözleşmeleri" olarak isimlendirmiştir. Bk. Albaraka Türk, Albaraka Türk 2011 Yılsonu Bağımsız Denetim Raporu (İstanbul: Albaraka Türk Katılım Bankası, 2011), 60. Sonrasında ise "vekale kredileri" şeklinde bir kullanım benimsemiştir. Bk. Albaraka Türk, Albaraka Türk 2013 Yılsonu Bağımsız Denetim Raporu (İstanbul: Albaraka Türk Katılım Bankas1, 2013), 41. Diğer yandan Kuveyt Türk Katılım Bankası denetim raporlarında ya da faaliyet raporlarında bu fonlar hakkında detaylı bilgi vermezken 2019 yılı faaliyet raporunda "wakala kredileri" olarak bu fonlardan çok kısaca bahsetmiştir. Bk. Kuveyt Türk, Kuveyt Türk 2019 Faaliyet Raporu (İstanbul: Kuveyt Türk Katılım Bankası, 2019), 101. Bu noktada İslami finanstaki Türkçe kullanımların gözden geçirilmesi ve daha makul, tutarlı tanımlayıcı terimlere olan ihtiyacı da belirtmemiz gerekmektedir. İslami finans alanında son dönemde sıklıkla kullanılan sermaye piyasası araçlarından olan sukuklar için Türkçede kira sertifikası ifadesinde olduğu gibi vekalet ile temin edilen uluslararası fonlar için de vekalet ile kredinin bir arada kullanılması yapılan işlemin yanlış tanımlanmasına neden olmaktadır. Bu nedenle ifade tutarlılıklarının ve yapılan işlemlerin tam karşılıklarının aktarılması amacıyla İslami finanstaki terimlerin kullanımı üzerine çalışmalar yapılmasına ihtiyaç vardır. 
2011 yılında itibaren katılım bankaları tarafından vekalet sözleşmeleri yoğun şekilde uluslararası piyasalardan fon temin etmek için kullanılmaya başlamıştır. TKBB'nin verileri yıllara göre vekalet kredilerinin tutarı hakkında bilgi vermektedir. Buna göre 2017 yılına kadar Albaraka Türk ve Kuveyt Türk vekalet yolu ile yüksek tutarda fon temin etmiş; ilgili dönemde Türkiye Finans ise görece bu yöntemi daha az kullanmıştır. 2015 yılında kurulan kamu katılım bankaları ise sınırlı bir şekilde vekalet kredilerine başvurmaktadır. Sektörün toplam vekalet kredisi ile temin ettiği fon miktarı 2017 yılında 5 milyar TL'ye yaklaşmıştır. 2019 yılsonunda ise bu miktar 1,3 milyar TL civarında gerçekleşmiştir. Vekalet ile temin edilen fonlar, muhasebe açısından alınan bir kredi olarak görülmektedir. Diğer bir ifade ile katılım fonları gibi değerlendirilmemekte, bilançonun pasif kısmında "alınan krediler" altında sınıflandırılmaktadir ${ }^{27}$.

Katılım bankaları yurt dışından fon temininde vekale kredilerinin yanında murabaha sendikasyon kredileri ve sukuk (kira sertifikası) ihraçlarını da kullanmaktadır. Ancak bu yöntemlerin hem vadeleri daha uzun hem de operasyonel süreçleri daha karmaşıktır. Murabaha sendikasyon kredilerinde ve sukuk ihraçlarında birçok kurumsal yatırımcı (çoğunlukla bankalar) ihraca katılmaktadır. Finansal tabloların sunulması, yurt dışı yatırımcı ziyaretlerinin (roadshow) yapılması, özellikle sukuk ihraçları için kredi derecelendirme ihtiyacı gibi süreçlere göre vekale hesaplarında işlemler çok daha basittir. Ayrıca vekale kredisi ile fon toplanan kuruluşların önemli bir kısmını ilgili katılım bankalarının ana bankacılık gruplarındaki kuruluşlar ve muhabir bankalar oluşturmaktadır ${ }^{28}$.

\subsection{Vekalete Dayalı Yatırım Hesapları}

Katılım bankaları tüzel ya da gerçek kişi müşterilerinden katılım fonları yolu ile fon toplama yetkisine sahiptirler. Herhangi bir getirinin sunulmadiğ cari hesaplar İslam fıkhındaki karz-ı hasen sözleşmesine göre temin edilmektedir. Bununla birlikte katılma hesapları kâr zarar paylaşımına dayalı olarak getiri sağlayan hesaplardır ve mudarebe sözleşmesine dayanmaktadır. Katılım bankalarının en temel fonksiyonlarını bu hesaplar oluşturmaktadır. Öyle ki katılım bankalarının katılım fonları içerisinde katılma hesaplarının payı

27 Albaraka Türk Katılım Bankası vekalet ile yurtdışından temin ettiği fonları denetim raporunda ayrı kalemlerde belirtmektedir. Buna göre "vekale kredileri" şeklinde ifade edilen bu fonlar "alınan krediler" kalemi altında tasnif edilmiştir. Bk. Albaraka Türk, Albaraka Türk 2019 Yılsonu Bă̆ımsız Denetim Raporu (İstanbul: Albaraka Türk Katılım Bankası, 2019), 92.

28 Albaraka Türk, Albaraka Türk 2019 Faaliyet Raporu (İstanbul: Albaraka Türk Katılım Bankası, 2011), 43 . 
2019 yılsonunda yüzde 66,5'tir. ${ }^{29}$ Geri kalan kısmını herhangi bir vadesi bulunmayan ve istenildiği zaman müşteriler tarafından çekilebilen özel cari hesaplar oluşturmaktadır.

2018 yılına kadar katılım bankaları sadece mudarebeye dayalı katılma hesapları yolu ile fon temin etmiştir. Ancak 18 Ekim 2018 tarihli 30569 sayılı Resmî Gazete'de yayımlanan "Mevduat ve Katılım Fonunun Kabulüne, Çekilmesine ve Zamanaşımına Uğrayan Mevduat, Katılım Fonu, Emanet ve Alacaklara İlişkin Usul ve Esaslar Hakkında Yönetmelikte Değişiklik Yapılmasına Dair Yönetmelik" 30 ile birlikte katılım bankalarının müşterilerine sunacakları yatırım vekaletine dayalı katılma hesapları düzenlenmiştir. BDDK bu düzenlemenin gerekçesini “... bu bankalara [katılım bankaları] kaynak sağlamada esneklik sağlanacağı ve bu sayede sektörün gelişmesinde önemli bir aşama kaydedeceği düşünülmektedir" şeklinde vurgulamıştır. ${ }^{31} \mathrm{Bu}$ düzenleme sektör açısından oldukça yapısal bir değişiklik getirmiştir. Bununla birlikte düzenleme öncesinde bazı katılım bankaları vekalet sözleşmesi kullanarak hem gerçek hem de tüzel kişilerden fon temin etmişlerdir. ${ }^{32}$ Yasal düzenleme olmadan ve fikhi konuda sektörde standartlar belirlenmeden işlemler gerçekleşmiştir. Bu tarz bir uygulamaya başvurulmasının sebebi müşterilere mudarebeye dayalı katılım hesaplarından daha yüksek bir kâr dağıtabilme ve konvansiyonel bankalar ile rekabet edebilmektir. Kısa bir süre bu şekilde bir ürün sunulmuş, sonrasında Ekim 2018' deki düzenleme ile uygulamanın yasal altyapısı oluşmuştur.

Tablo 2: Mudârebe Katılma Hesabı ile Yatırım Vekaleti Hesabının Karşılaştırması

\begin{tabular}{lll}
\hline Özellik & Mudârebe Katılma Hesabı & Yatırım Vekaleti Hesabı \\
\hline Sözleşme Türü & Mudârebe & Vekalet \\
\hline Müşteri Türü & Gerçek ve tüzel kişi & Sadece tüzel kişiler \\
\hline Getiri & Ortaklık sonucunda doğan & Tahmini kâr oranı üzerinden \\
& kâr/zarar başta belirlenen kâr & anlaşılmaktadır. Müşterinin \\
& paylaşım oranı üzerinden katı- & alabileceği maksimum tutar \\
& lim bankası ile katılma hesabı & anaparası ve tahmini tutar ka- \\
& müşterisi arasında paylaşıl- & dardır. \\
& maktadır. & \\
\hline
\end{tabular}

29 Bankacılık Düzenleme ve Denetleme Kurumu (BDDK), BDDK Aylık Bülteni (Aralık 2019).

30 Mevduat ve Katılım Fonunun Kabulüne, Çekilmesine ve Zamanaşımına Uğrayan Mevduat, Katılım Fonu, Emanet ve Alacaklara İlişkin Usul ve Esaslar Hakkında Yönetmelik, Resmi Gazete 30569 (18 Ekim 2018), md. 4,6.

31 TKBB Danışma Kurulu, “Karar No 2: Yatırım Vekaleti” (30 Haziran 2018).

32 Kişisel görüşme ile bu işlemi gerçekleştiren katılım bankası personelinden bilgi alınmış ve sektörde diğer bir katılım bankası tarafından da uygulandığı başka bir katılım bankasının personelinden teyit edilmiştir. 


\begin{tabular}{lll}
\hline $\begin{array}{l}\text { Kâr } \\
\text { Dengeleme } \\
\text { Rezervi }\end{array}$ & $\begin{array}{l}\text { Sadece katılma hesapları sahip- } \\
\text { leri için kullanılmak üzere kâr } \\
\text { dengeleme rezervi ayrılabilir. }\end{array}$ & $\begin{array}{l}\text { Sadece yatırım vekaleti hesabı sa- } \\
\text { hipleri için kullanılmak üzere kâr } \\
\text { dengeleme rezervi ayrılabilir. }\end{array}$ \\
\hline Vade & $\begin{array}{l}1 \text { ay, } 3 \text { ay, 6 ay, 1 yıl ve daha } \\
\text { uzun vadeli açlabilmektedir. }\end{array}$ & $\begin{array}{l}1 \text { ay, } 3 \text { ay, } 6 \text { ay, } 1 \text { yıl ve daha uzun } \\
\text { vadeli açılabilmesinin yanında bir } \\
\text { aydan daha kısa vadeli de açılabil- } \\
\text { mektedir. }\end{array}$ \\
\hline
\end{tabular}

\begin{tabular}{lll}
\hline Yenilenme & $\begin{array}{l}\text { Vade sonralarında ilgili dö- } \\
\text { nemdeki kâr paylaşım oranı } \\
\text { üzerinden yenilenmektedir. }\end{array}$ & $\begin{array}{l}\text { Vade tarihinde yenilenmemekte- } \\
\text { dir. Yeni bir sözleşme yapılması } \\
\text { gerekmektedir. }\end{array}$ \\
\hline $\begin{array}{l}\text { Kâr/Zarara } \\
\text { Katılma }\end{array}$ & $\begin{array}{l}\text { Kâr ya da zarara katılma söz } \\
\text { konusudur. }\end{array}$ & Kâr ya da zarara katılma yoktur. \\
\hline $\begin{array}{l}\text { Anapara } \\
\text { Garantisi }\end{array}$ & Anapara garantisi yoktur. & Anapara garantisi yoktur. \\
\hline $\begin{array}{l}\text { Faaliyet Alanı } \\
\text { Sinırlandırma }\end{array}$ & Sinırlandırılabilir. & $\begin{array}{l}\text { Genel ya da sinırlı bir yetkilen- } \\
\text { dirme yapılabilir. }\end{array}$ \\
\hline
\end{tabular}

Düzenleme ile kâr zarar ortaklığına dayalı olan katılma hesaplarıyla birlikte vekalete dayalı olarak da müşterilere katılma hesabı açılmasının önü açılmıştır. Bu hesap türleri arasında benzerliklerle birlikte önemli işleyiş farklılıkları bulunmaktadır (Tablo 2). "Yatırım vekaletine dayalı katılma hesabı" 33 olarak isimlendirilen hesaplar, mudarebe katılma hesaplarından farklı olarak sadece "kamu kurum ve kuruluşları ile fonlar ve tüzel kişilere" açılabilmektedir. ${ }^{34}$ Gerçek kişi müşteriler bu hesapların dışında tutulmuştur.

Yatırım vekaletine dayalı katılma hesaplardaki en önemli husus hesabı açan müşterilere sunulan tahmini kâr ile ilgilidir. Katılma hesaplarında müşterilerin bildiği ve hesap cüzdanında yazan oran kâr/zarar katılım oranıdır. Örneğin kâr zarar katılma oranı \%80 olarak belirlendiğinde, müşteri elde edilecek kârın \%80'inini, katılım bankası ise \%20'sini almak üzere anlaşmaktadır. Bununla birlikte katılım bankaları her gün internet sitelerinde vadelere göre tahakkuk etmiş dağıtılan kâr paylarını da yayınlamaktadır. Ancak bunlar sadece bir referans olarak sunulmakta olup yeni hesap açan müşterilere yönelik bir taahhüt ya da sözleşmeleri içerisinde bir unsur değildir. Bununla birlikte

33 Düzenleme Resmî Gazete' de yayımlanmadan önce BDDK tarafından 24.05.2018 tarihli yazı ile TKBB Danışma Kurulu'ndan görüş talep edilmiştir. Bu yazı üzerine TKBB Danışma Kurulu taslak metindeki maddelerin bazılarına yönelik 20.06.2018 tarihli toplantılarında önerilerde bulunmuştur. Bu anlamda taslaktaki "vekalet" ifadelerinin yerine "yatırım vekaleti" kullanılması, bu kavramın yapılan işlemi daha açık ve net şekilde tanımladığı gerekçeli görüşü üzerine revize edilmiştir. TKBB Danışma Kurulu, "Karar No 2: Yatırım Vekaleti" (30 Haziran 2018).

34 Mevduat ve Katılım Fonunun Kabulüne, Çekilmesine ve Zamanaşımına Uğrayan Mevduat, Katılım Fonu, Emanet ve Alacaklara İlişkin Usul ve Esaslar Hakkında Yönetmelik, md. 6(2). 
vekalete dayalı katılma hesaplarında hesap sahibi ile katılım bankası arasında tahmini kâr belirlenmektedir. Bu oran katılım bankası tarafından fonun değerlendirilmesi sonucunda kâr elde edilmesi durumunda "hesap sahibi ile katılım bankası arasında fonun işletilmeye başlandı ğı tarihten önce mutabık kalınan ve bu kârdan katılma hesabı sahibinin gerçekleşen kârı geçmemek üzere hak iddia edebileceği azami oran" 35 olarak tanımlanmıştır. ${ }^{36}$ Tahmini kâr hesap açılması tarihinde belirlenmekte ve vade sonuna kadar değiştirilememektedir. ${ }^{37}$ Bununla birlikte katılım bankaları, her iki tür katılma hesabı için de yine bu hesaplar adına kullanılmak üzere kâr dengeleme rezervi ayırabilirler. ${ }^{38}$

Vekalete dayalı katılma hesapları kâr zarar katılma hesaplarından minimum vade konusunda da farklılaşmaktadır. Katılma hesaplarında toplanan fonlar finansman olarak müşterilere kullandırılmakta (kredi) ve bunlardan elde edilen kâr, katılma hesapları sahipleri ile paylaşılmaktadır. Kredilerin taksit ödemeleri de en kısa vade olarak aylık olmaktadır. Bu nedenle mudarebeye dayalı katılma hesaplarında minimum vade 1 ay olarak belirlenmiştir. Ancak vekalete dayalı hesaplarda toplanan fonlar 1 aydan daha kısa vadeli olarak da açılabilmektedir. ${ }^{39}$ Kredi işlemleri yerine daha kısa vadeli gelir getirici alanlarda kullanılması gerekmektedir.

Diğer yandan vekalete dayalı katılma hesapları kâr zarar katılma hesaplarından farklı olarak vade sonunda yenilenmemekte, fon özel cari hesaba aktarılmaktadır. ${ }^{40}$ Tekrardan müşteri ile katılım bankası arasında şartların (tahmini kâr, vade, vb.) belirlenip yeni bir sözleşme yapılması gerekmektedir. Bu

TKBB Danışma Kurulu taslak metinde "beklenen kâr" olarak kullanılan ifadeye "faizde olduğu gibi sabit bir getiriyi çağrıştırdı̆̆g" gerekçesi ile karşı çıkmış ve sundukları teklif üzerine ilgili ifade "tahmini kâr" olarak değiştirilmiştir. Yine ayn gerekçe ile taslaktaki metinde tanımın sonu "hak iddia edebileceği azami oranı veya tutarı" şeklindeyken "tutar" kelimesi ile revize edilmiştir. TKBB Danışma Kurulu, "Karar No 2: Yatırım Vekaleti” (30 Haziran 2018). $\mathrm{Bu}$ tanımla ilgili kurul kararının ana metninde bulunmayan ancak bir kurul üyesinin ilgili karara yönelik yazdığı şerhte önerdiği tanıma "gerçekleşen kârı geçmemek üzere" ifadesinin eklenmesine yönelik tavsiyesi de BDDK tarafından dikkate alınarak düzenlemenin nihai haline eklenmiştir.

36 Mevduat ve Katılım Fonunun Kabulüne, Çekilmesine ve Zamanaşımına Uğrayan Mevduat, Katılım Fonu, Emanet ve Alacaklara İlişkin Usul ve Esaslar Hakkında Yönetmelik, md. 3 $(1 / b)$.

37 Mevduat ve Katılım Fonunun Kabulüne, Çekilmesine ve Zamanaşımına Uğrayan Mevduat, Katılım Fonu, Emanet ve Alacaklara İlişkin Usul ve Esaslar Hakkında Yönetmelik, md. 4 $(4 / d)$.

38 Mevduat ve Katılım Fonunun Kabulüne, Çekilmesine ve Zamanaşımına Uğrayan Mevduat, Katılım Fonu, Emanet ve Alacaklara İlişkin Usul ve Esaslar Hakkında Yönetmelik, md. 6 (8).

39 Ziraat Katılım, Ziraat Katılım 2019 Yılsonu Bă̆ımsız Denetim Raporu (İstanbul: Ziraat Katılım Bankası, 2019), 3.

40 Mevduat ve Katılım Fonunun Kabulüne, Çekilmesine ve Zamanaşımına Uğrayan Mevduat, Katılım Fonu, Emanet ve Alacaklara İlişkin Usul ve Esaslar Hakkında Yönetmelik, md. 4 $(4 / \mathrm{e}), 6(7)$. 
farklılıkların yanında iki tür katılma hesabında da anapara garanti altına alınmamaktadır. ${ }^{41}$ Müşteriler vekalet ile katılım bankasına verdikleri fonların kullanımına ilişkin genel ya da sınırlı yetkilendirmede bulunabilirler. ${ }^{42}$

Yapılan bu düzenleme ile katılım bankaları vekalete dayalı hesaplar açarak tüzel kişi müşterilerine bu ürünü yasal olarak şartları belirlenmiş bir şekilde sunma imkanına sahip olmuşlardır. Katılım bankaları tarafından bu mevzuat çerçevesinde hazırlanan sözleşmeler uygulama hakkında bilgi vermektedir. Katılım bankalarının internet sitelerinde ve 2019 faaliyet raporlarında vekalete dayalı katılma hesaplarının vade, toplanan tutar, vekalet ücretleri gibi özellikleri hakkında pek bilgi bulunmamakla birlikte, Türkiye Finans ve Albaraka Türk sitelerinde genel şartları içeren sözleşmeleri paylaşmıştır. Buna göre hesap açılmasında müşterilerle yapılan sözleşmelerde, düzenlemede kendilerine sunulan alternatifler içerisinde hareket edilmiştir. Örneğin vekalet hesaplarında tanımlanan yetkilendirmeyi katılım bankaları "genel" yetki olarak kullanmaktadırlar. ${ }^{43}$ Diğer bir ifade ile katılım bankası vekil sıfatı ile kendisine verilen fonları katılım bankacılığı prensipleri içerisinde olmak üzere herhangi bir sınırlandırma (sektörel vs.) olmadan değerlendirebilmektedir. Diğer taraftan Türkiye Finans sözleşmedeki 7. maddede gerçekleşen kârın tahmini kârı geçmesi durumunda müşterinin ancak tahmini kâr kadarını alabileceğini de vurgulamaktadır. ${ }^{44}$ Bununla birlikte Albaraka Türk madde 4'te “Tahmini kârın üzerinde gerçekleşen kârın tamamı Banka'ya aittir" ifadesiyle işleyişi açıklamıştır. ${ }^{45}$

\section{Uygulama ve Fıkhi Açılardan Vekalet Katılım Hesaplarının Tahlili}

\subsection{Uygulama Açısından Tahlil}

Katılım bankalarının fon toplama yöntemlerinde oldukça önemli bir yapısal değişiklik getiren vekalete dayalı katılma hesapları fıkhi noktalardaki ihtilaflı özelliklerinin yanında uygulama açısından da incelenmesi gereken hususları barındırmaktadır. Uygulama süreçleri ile ilgili olan bu hususların analiz edilmesi ilerleyen dönemlerde Türkiye' deki katılım bankacılığına yönelik bu tarz yapısal kararların alınmasında yol gösterici olabilecektir.

Katılım bankalarının vekalete dayalı yatırım hesaplarını kullanmaya başlama gerekçesini anlayabilmek için fon tarafındaki müşterilerin faizsizlik prensibi ve getiri konusundaki hassasiyetlerinin değerlendirilmesine ihtiyaç

41 Mevduat ve Katılım Fonunun Kabulüne, Çekilmesine ve Zamanaşımına Uğrayan Mevduat, Katılım Fonu, Emanet ve Alacaklara İlişkin Usul ve Esaslar Hakkında Yönetmelik, md. 6 (1).

42 Mevduat ve Katılım Fonunun Kabulüne, Çekilmesine ve Zamanaşımına Uğrayan Mevduat, Katılım Fonu, Emanet ve Alacaklara İlişkin Usul ve Esaslar Hakkında Yönetmelik, md. 6 (3).

43 Türkiye Finans, "Yatırım Vekaletine Dayalı Katılma Hesabı Sözleşmesi" (2020); Albaraka Türk, "Yatırım Vekaleti Sözleşmesi" (2020).

44 Türkiye Finans, "Yatııım Vekaletine Dayalı Katılma Hesabı Sözleşmesi” (2020).

45 Albaraka Türk, "Yatırım Vekaleti Sözleşmesi" (2020). 
vardır. Bu konu ile ilgili kesin bir oran verilemese de yapılan bazı çalışmalar bir fikir sunmaktadır. Bu bağlamda farklı mevduat/katılım fonu tutarlarına sahip müşteri bakiyeleri üzerinde yapılan çalışmalarda, faiz oranlarındaki değişikliklere katılma hesabı sahiplerinin hassasiyet gösterdikleri ve bu hassasiyetin tutar arttıkça daha da yükseldiğini ortaya konulmuştur. ${ }^{46}$ Buna göre piyasadaki faiz oranları arttığında katılım bankalarında parasını tutan -fon miktarı açısından- büyük müşteriler mevduat bankalarına kayabilmektedir. Bunun sonucu olarak katılım bankalarından fon çıkışı olmaktadır. Ancak getiri hassasiyetine sahip ve faizsizlik prensibini dikkate almayan bu tarz fonlarin toplam içerisindeki payının ne kadar olduğunu tahmin edebilmek mümkün olmamaktadir.

Katılım bankalarının dağıttıkları kâr payları piyasa faizlerinin hızlı arttığı dönemlerde mevduat bankalarının faiz oranlarının altında kalabilmektedir. ${ }^{47}$ Böyle durumlarda aradaki makas artmakta ve katılım bankaları özellikle büyük montanlı fonları olan müşterilerini tutmakta zorlanmaktadır. Şekil 2'de görüldüğ̈̈ üzere katılım bankalarının katılma hesaplarına dağıttığı ortalama kâr payı ile mevduat bankalarının ağırlıklı mevduat faizi arasındaki fark 2017 yılından itibaren artmaya başlamış ve bu artış 2018 Haziran ayındaki TCMB'nin politika faizindeki yüksek artışla birlikte çok daha hızlanmıştır. Vekalete dayalı katılma hesaplarıyla ilgili düzenlemenin çıktığı Ekim 2018'de kâr payları ile faiz oranları arasındaki fark yüzde 10'lara yaklaşmıştır.

Şekil 2: Katılma hesaplarına dă̆̊tılan kâr payları ve mevduat faizi karşılaştırması (\%)

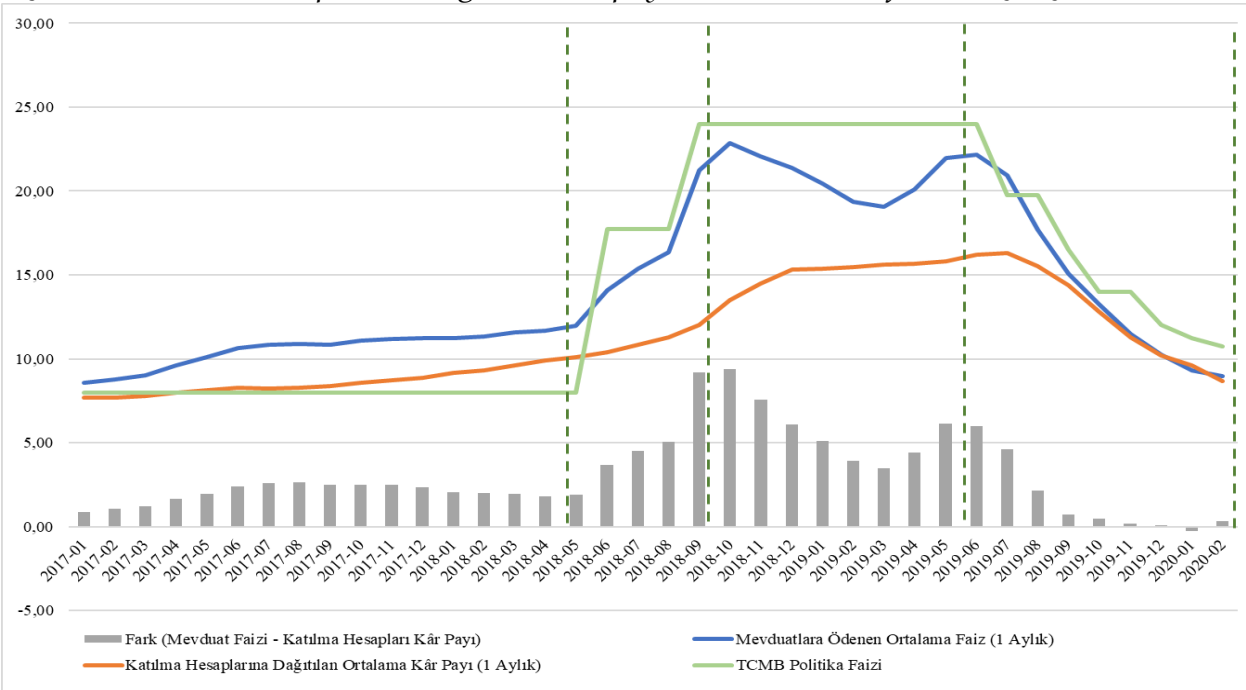

46 Ahmet Faruk Aysan vd., "Religiosity versus Rationality: Depositor Behavior in Islamic and Conventional Banks", Journal of Comparative Economics 46/1 (2018), 1.

47 Bu durumun tam tersinde yani faizlerin hızlı düştüğü dönemlerde de katılım bankaları mevduat bankalarının faizleri üzerinde bir kâr payı dağıtabilmektedir. 
Kaynak: TCMB Elektronik Veri Dağıtım Sistemi (https://evds2.tcmb.gov.tr/) ve TKBB Veri Seti'nden (https://www.tkbb.org.tr/ veri-seti) hesaplanarak oluşturulmuştur (Erişim Tarihi: 18.04.2020).

Bu durum katılım bankalarının daha yüksek kâr payı verebilecekleri, esneklik sağlayan ve mudarebeye dayalı hesaplardaki gecikmeyi içermeyen vekalete dayalı katılma hesaplarına ihtiyacı artırmıştır ${ }^{48} .2018$ yılında bazı katılım bankaları bu nedenle yasal düzenleme olmadan vekaletle fon toplamıştır. Aynı zamanda üzerinde ihtilaf bulunan teverrukü de kullanmışlardır. ${ }^{49}$ Temel amaç yüksek miktarlı fona sahip müşterilerin katılım bankasında tutulmasıdır. 2019 yılının ortalarından itibaren TCMB'nin faiz indirimleri ile katılım bankaları kâr paylarıyla mevduat faizleri arasındaki makas kapanmış ve 2019 yılsonunda neredeyse sıfırlanmıştır (Şekil 2).

Katılma hesabı sahiplerinin getiriye olan hassasiyetlerinin yanında katılım bankaları açısından da meselenin ele alınması gerekmektedir. Fon kaynağı noktasında katılım bankaları hala ciddi sıkıntı ile karşı karşıya kalmaktadır. Uluslararası piyasaların İslami finans açısından çok fazla gelişmemiş olması, âtıl fonları kısa vadeli olarak değerlendirmeyi zorlaştırmasının yanında katılım bankalarının uygun maliyetlerle ek kaynaklara ulaşmasını da engellemektedir. Bununla birlikte sukuk ve murabaha sendikasyonu gibi alternatif fon kaynaklarının operasyonel süreçleri, yurt dışında artan faizlere paralel olarak ortaya çıkan yüksek maliyetler bu yöntemlerin kullanılmasını katılım bankaları açısından zorlaştırmaktadır. Diğger yandan yurt içinde faizsiz likidite piyasaları da oldukça sınırlıdır. Bu nedenlerle katılım bankalarının en önemli fon kaynağını yurt içindeki tasarruflar oluşturmaktadır. Türkiye' deki düşük tasarruf oranı ve katılım bankalarının konvansiyonel bankalarla aynı sistemde rekabet etmesi gibi yapisal sorunlar da fon temini konusunda engel

48 Bu noktada katılım bankalarının vekalete dayalı katılma hesaplarındaki fonları farklı bir finansman metodu kullanarak $\mathrm{mı}$ değerlendireceği ve mudârebe katılma hesaplarından daha yüksek getiriyi ne şekilde sağlayabileceği soruları ortaya çıkabilir. İslami bankalar metinde bahsedilen dünyadaki uygulamalar ve atıflarda da görüldügü üzere daha rekabetçi olabilmek için belirli limitlerin üzerindeki fon sahiplerine vekalet hesaplarını sunmaktadır. Mevcut durumda katılım bankaları, mudârebeye dayalı katılma hesaplarına tutar ve vadelere göre farklı kâr paylaşım oranları belirleyebilmektedir. Vade ve tutar arttıkça müşteri lehine kâr paylaşım oranı artmaktadır. Bk. Kuveyt Türk, "Katılma Hesabı: TL Katılma Hesapları" (Erişim 12 Kasım 2020). Burada elde edilen fonlar neredeyse tamamen murabahada değerlendirilmektedir. Vekalette ise yine meşru alanlarda ve fikhi sözleşmelerle bu fonlar değerlendirilmekte ama farklı havuzlarda fonlar işletilmektedir. BDDK'nın düzenlemesinde ve verilen fetvalarda da mudârebe katılma hesaplarından farklı havuzlarda olduğu belirtilmektedir. Bk. Albaraka, "Yatırım Vekaleti Sözleşmesine Dayalı Katılma Hesabı" (Erişim 12 Kasım 2020). Bu noktada finansman tarafında yöntem değişmese bile katılım bankası kendi kârından vekalet hesaplarındakilere feragatta bulunabilir ya da fonları değerlendirirken daha yüksek kâr edilebilecek alanlara yönlendirebilir. Böylece mevcut mudârebe katılma hesaplarından daha yüksek oranda tahmini kâr sunma imkanına sahiptir.

49 İslam İktisadı, “Katılım Bankaları ve Yatırım Vekaleti Hesapları” (Erişim 15 Nisan 2020). 
teşkil etmektedir. Bu nedenle, katılım bankalarının fon temin ederken getiri hassasiyeti olan müşterileri de düşünmesi kendi içinde tutarlı bir durum oluşturabilir. Ancak burada piyasa baskısının, katılım bankalarının alameti farikası olan faizsizlik prensibine yönelik bir soru işareti oluşturabilecek adımlar attırmaması gerekmektedir.

Vekalete dayalı katılma hesapları, her ne kadar hem TKBB Danışma Kurulu hem de katılım bankalarının kendi danışma kurullarının onayından geçmiş olsa da böyle bir endişeyi doğurmaktadır. Buradaki temel sorunlardan biri gelecekte piyasa baskısı nedeniyle katılım bankalarının, kendilerini özgün kılan (belki de varlık sebebi olan) kâr zarar ortaklığına yani mudârebeye dayalı yapılarıyla çelişebilecek uygulamalara başvurabileceği ihtimalidir. Ancak vekalete dayalı katılım hesapları ile her ne kadar "tahmini" denilse de sabit bir getiri belirtilmesi katılım bankalarının toplumdaki faizsizlik, ortaklığa dayalı yapı imajlarını zedeleyebilir ve diğer faizli bankalarla benzer şekilde iş yapıyor algısını artırabilir. Çünkü vekalet hesaplarının açılmasının gerekçesi getiri hassasiyeti yüksek olan müşterilerin tatmin edilmesi ve faizli bankalara yönelmelerinin engellenmesidir. Bu gerekçe ile yola çıkıldı̆̆ında tahmini tutarın altında bir getirinin bu kesime verilebileceğini düşünmek çok gerçekçi gelmemektedir. En iyi ihtimalle katılım bankası başka kaynaklardan bunu telafi etme yoluna gidebilecektir. Aksi takdirde böyle bir hesabın açılmasının kendi içinde tutarlı bir yanı kalmamaktadır.

Vekalet hesaplarındaki tahmini kâr ile alakalı bu endişeyi, TKBB Danışma Kurulu'nun da yaşadı̆̆ı ve BDDK'ya verdikleri görüş yazısına yansıttıkları görülmektedir. Yapılan düzeltme tavsiyeleri hep işlemin "sabit bir getiriyi" çağrıştırabileceği yönündedir. ${ }^{50}$ Diğer taraftan katılım bankalarının sitelerinde vekalete dayalı katılma hesapları ile ilgili neredeyse hiç bilgi sunmamaları ve aktif bir pazarlama stratejisi benimsememeleri bu çekince ile ilgili olabilir.

Mevcut gerekçenin diğer bir olumsuz sonucu, Gresham Yasasındaki kötü paranın iyi parayı kovması gibi İslami açıdan üzerinde ihtilafların bulunduğu sözleşme türlerinin İslami finansın ideal yöntemlerini kovabileceği riskidir. Finansman tarafında murabaha işleminde görüldüğü üzere bir süre sonra ortaklık finansmanlarının hiç kullanılmaması sorunu doğabilmektedir. Çünkü piyasadaki rekabetin bunu [murabahayı] gerektirdiği argümanı ikna edici olmaktadır ve alternatif metotlar düşünülmek yerine daha kısa vadeli pragmatist bir tavır benimsenmektedir. Diğer yandan organize teverruk uygulaması

50 TKBB Danışma Kurulu, “Karar No 2: Yatırım Vekaleti” (30 Haziran 2018). 
sınırlı bir şekilde sadece ekonomik durumu sıkıntıya düşmüş kişiler ${ }^{51}$ için kul-

lanılacakken bu yöntemin yaygınlaştığı ve teverruke dayalı olarak tüketim ihtiyaçlarını çözecek ürünlerin çıktığı görülmektedir. ${ }^{52}$ Aynı durumun vekalete dayalı hesaplar için de geçerli olabilme ihtimali bir risk olarak karşımızda durmaktadır. Bu riskin TKBB Danışma Kurulu tarafından da hissedildiği ve önüne geçmek için çaba sarf edildiği anlaşılmaktadır. Öyle ki görüşlerinde mevzuata "bir katılım bankasının yatırım vekaleti ile işletebileceği azami fonun, bankanın mudarebe esaslı kâr ve zarara katılma hesaplarının belirli bir oranını geçmemesini sağlayacak bir ifadenin de eklenmesi" önerisinde bulunmuşlar ancak mevzuata yansımamıştır. Gerekçe olarak da mudarebeye dayalı katılma hesaplarının katılım bankacılığının "belkemiği” olduğu ve "büyük oranda ortadan kalkmaması gerektiği" ileri sürülmüştür. Böyle bir hassasiyete ihtiyaç bulunduğu aşikardır. Aksi takdirde dünyadaki örneklerde görülebileceği üzere "ihtiyaç" ya da "piyasa rekabetinin" gerektirmesi durumunda teverruke dayalı olarak fon toplamanın önünün açılmayacağının nasıl garanti edilebileceği sorusuna tatmin edici bir cevap verilmesi zorlaşmaktadir.

BDDK sadece tüzel kişilere yönelik vekalete dayalı hesaplarının açılmasına izin vermiştir. Böylece mudarebe hesaplarının yaygınlığı devam edebilecektir. Ancak bu da beraberinde yine gerekçedeki durumla alakalı olarak farklı bir olumsuz sonucu doğurabilir. Bireysel müşterilere açılan mudarebe katılma hesaplarındaki kâr payı ile vekalet katılma hesaplarındaki kâr payı arasında anlamlı bir fark oluşabilir. Bu da bireysel müşterilerde bir memnuniyetsizliğe ve katılım bankasına yönelik olumsuz bir bakış açısına sebep olabilecektir. Böyle bir durumun yaşanması sektör açısından vekalet hesapları ile umduğu fon kaybını telafi etme planının tersine işlemesine neden olabilir. Benzer şekilde bu sefer bireysel müşterilerin oluşturduğu piyasa baskısı yasal bir düzenleme değişikliği ile bu hesapların mudarebe katılma hesaplarındaki gibi tüm müşterileri kapsamasına etki edebilir. Böyle bir durumda ilk bahse-

51 Prof. Dr. Hayrettin Karaman, katılım bankalarının teverruk ürünü kullanmalarına şu durumlar altında izin verdiklerini belirtmektedir: "Katılım bankaları için bu konuyu müzakere ettiğimizde -caiz görülse bile- şekle değil de maksada bakarak bunun, normal hallerde bir banka işlemi olarak değil, dara düşenler, sıkışanlar, kaynak elde edemediği takdirde önemli zarara uğrayacak olanlar, hâsılı zaruret sayılan ihtiyaç halinde kullanılmasına karar verdik." Bk. Hayrettin Karaman, “Teverruk”, Yeni Şafak (2 Kasım 2018).

52 Örnek olarak Türkiye Finans Katılım Bankası tarafından "dert çözen finansman” adı altında müşterilere sunulan finansman türü teverruka dayanmaktadır. Tanıtım yazısında bu finansman türünün "kişinin evinin boyasından eğitim masraflarına, sağlık harcamalarından evlilik giderlerine kadar katılım bankacılığ prensipleri dahilinde tüm alışverişlerinde kullanım imkânı sağladığı" ifade edilmektedir. Bk. Türkiye Finans, "Dert Çözen Finansman”. (Erişim 13 Kasım 2020). 
dilen sınırlı kullanım artacak ve mudarebe katılma hesaplarının ortadan kalkmasını engelleyecek TKBB Danışma Kurulu'nun önerdiği gibi bir kısıtlamaya ihtiyaç daha da artacaktır.

Sonuç olarak vekalete dayalı katılma hesaplarının ortaya çıkmasının gerekçesi bazı sıkıntıları barındırmakta ve ilerisi için riskler içermektedir. Bununla birlikte ârizi bir durum için böyle bir kararın etkili olduğu, ancak yan etkilerinin çok daha geniş olacağının unutulmaması gerekmektedir. Öyle ki Şekil 2'te görüldüğü üzere düşük faiz ortamında bu getiriler yakınsamakta hatta kısa dönemde katılım bankaları için olumlu da sonuçlanabilmektedir. Bu nedenle, kısa vadeli getiriler için yapısal değişiklikleri uygularken çok dikkat edilmesi gerekmektedir. Aksi taktirde katılım bankalarına özgü bir risk olan Şer'i Risk oluşabilir. Bu durum, katılım bankalarının toplumdaki itibarlarının zedelenmesine neden olabilir ve uzun vadede aşılması zor sorunlar getirebilir. Vekalete dayalı katılma hesaplarının da, katılım bankacılığının en önemli yapı taşı ve yukarıda da ifade edildiği gibi belkemiği olan mudarebeye dayalı kâr zarar katılma hesaplarını zedeleyebileceği hususu bu kapsamda değerlendirilmelidir. Piyasa baskısı İslamilik pahasına adımlar atılmasına gerekçe olmamalıdır. Bununla birlikte sorun sadece katılım bankalarının ya da düzenleyicilerin üzerine yüklenemez. Talep tarafında faizsizlik prensibini takip eden tüzel ve gerçek kişi müşteriler ve diğer paydaşlar, katılım bankalarının hem nicelik hem de nitelik açısından daha iyi duruma gelmesinde piyasa baskısını bu anlamda pozitif yönde kullanmalıdır. Ancak bu şekilde katılım bankalarından beklenen ideallere ulaşılabilir.

\subsection{F1khi Tahlil}

Yatırım vekaleti uygulaması, klasik fıkıhta öngörülen vekalet sözleşmesinden bazı yönlerden ayrılması sebebiyle birtakım fıkhi problemler barındırmaktadır. Yatırım vekaletinin fıkhi yönü ile ilgili en önemli problem, banka ile müşteri arasında baştan belli bir miktarın belirlenmesidir. Şekil itibariyle mudarebe akdine benzeyen yatırım vekaletini mudarebeden ayıran temel özellik de budur. Konuyla ilgili görüş beyan eden çağdaş araştırmacılar, belirli bir getiri üzerinde anlaşmayı içeren yatırım vekaleti uygulamasının İslami bankacılık işlemlerini geleneksel bankacılığa çok yaklaştırdığını, hatta iki sistem arasındaki faizsizlik ilkesine dayalı temel farkı kapattığını iddia etmektedirler. Bunun sebebi, sabit getirili işlemin fiili olarak faizli işlemle aynı mahiyette olacağı düşüncesidir. ${ }^{53}$ Buna karşılık uygulamayı faydalı bulanlar, vekilin müvekkile verdiği taahhüdün asıl itibariyle vekalet akdini geçersiz kılan taahhütlerden olmadığını dile getirmektedir. Vekalet akdi, belli konularda sınırlamalar getirmenin caiz olduğu akitlerden olup vekilin, ileri sürülen şartlara

53 İKTISAT, “Katılım Bankacılığının Ruhuna el-Fatiha mı?”. 
riayet etmesi gerekir. Ayrıca burada tahmini kâr üzerinden birim hesap değerine bir üst sınır getirilmiş ve katılım bankalarının havuz içerisinde çalışmasına imkân verilmiş olmaktadır. ${ }^{54}$

Yatırım vekaletiyle ilgili fikhi problemler, uygulamanın fikıhtaki genel akit mantalitesine veya vekalet akdinin doğasına aykırı olması sebebiyle ya da faiz yasağıyla ilgili kaidelere mutabakatta sorunlu görünmesi sebebiyle ortaya çıkmaktadır. Bu problemler; yatırım vekaletinin her iki taraf açısından bağlayıcı olması, kâr ile ilgili problemler ile yatırım vekilinin tazmin sorumluluğuna dair problemlerdir. Çalışmanın bu kısmında söz konusu problemler, sırayla ele alınacaktır.

\subsubsection{Yatırım Vekaletinde Bağlayıcılık}

İslam hukukunda vekalet akdi, ivazlı akitler kapsamında olmadığından taraflar açısından bağlayıcı değildir ve iki taraf da istedikleri zaman akdi sonlandırabilmektedir. ${ }^{55}$ Bununla birlikte Maliki mezhebinde ücretli vekalet, hizmet akdi niteliğinde görülmüş ve vekilin işe başlamasından sonra bağlayıcı kabul edilmiştir. ${ }^{56}$ Yatırım vekaleti işleminin, klasik fıkıhtan bağlayıcılık noktasında ayrıldı̆̆ı görülmektedir. AAOIFI'nin konuyla ilgili kararına göre, yatırım vekaleti her iki taraf açısından da bağlayıcıdır. Bununla birlikte, akitte taraflardan herhangi birine belirli durumlarda fesih yetkisi veren bir şart ileri sürülebilir. ${ }^{57}$ AAOIFI'de bağlayıcılığın dayanağı olarak, işlemin belirli bir süreyle sınırlı olarak yapılması hususu gösterilmiştir. ${ }^{58}$ Uygulamada yatırım vekaleti sözleşmesinin, belirli riskleri minimize etmek için bağlayıcı olarak kurulduğu görülmektedir.

İşlemin bağlayıcılık noktasında klasik fıkıhtan ayrılmasının birtakım nedenleri olduğu açıktır. Öncelikle söz konusu kararın alınma sebebinin, işlemleri tarafların cayma riskinden korumak olduğu anlaşılmaktadır. Buna ilave olarak tarafların, gelecek hakkında öngörülebilir tahminlerde bulunma isteğinin de bu noktada etkili olduğu görülmektedir. Bu karar, klasik fıkıhta bedelsiz olan ve yardımlaşma tarafı öne çıkan vekalet akdinin günümüzde arka planda farklı bir zihnî çerçevede değerlendirildiğini göstermektedir.

54 İslam İktisadı, “Katılım Bankaları ve Yatırım Vekaleti Hesapları”.

55 Kemâlüddîn İbnü'l-Hümâm, Fethu'l-kadîr (Beyrut: Dâru'l-Kütübi'l-İlmiyye, 2003), 147.

56 Ebû Abdullâh Şemsüddîn Hattâb, Mevâhibu'l-celîl li-şerhi Muhtasarı Halîl, (Riyad: Dâru Âlemi'l-Kütüb, 2003), 169; Aybakan, “Vekalet”, 43/2.

57 Accounting and Auditing Organization for Islamic Financial Institutions (AAOIFI), Faizsiz Finans Standartları (İstanbul: Türkiye Katılım Bankaları Birliği Yayınları, Yayın No: 10, 2018), 1087.

58 AAOIFI, Faizsiz Finans Standartları, 1096. 


\subsubsection{Yatırım Vekaletinde Kâr}

İslam hukukunda kural olarak vekaletten elde edilecek kârın tamamı müvekkile aittir. ${ }^{59}$ Burada taraflar arasında bir ortaklık ilişkisi bulunmadığından, vekil konum itibariyle sadece aracıdır. Yatırım vekaleti uygulamasında ise tahmini kârın üzerinde elde edilen getirinin vekile bir prim (ödül) olarak verilmesinin caiz olduğu karara bağlanmıştır. Bu durumda prim olarak verilen miktar, vekilin ücretine ek bir gelir olur. ${ }^{60} \mathrm{Bu}$ hükmün dayanağı, söz konusu işlemin belli bir şartın gerçekleşmesine bağlı bağışlama (hibe) niteliğinde olmasıdır ${ }^{61}$ İşlemin bu şekilde yapılacağına dair bir zorunluluk görünmemekle birlikte, uygulamada beklenen kârın üzerindeki miktarın bankada bırakıldığı anlaşılmaktadır. Ayrıca vekile kârdan prim verilebilmesi için kural olarak müvekkilin rızası gereklidir. Yatırım vekaletinde, müşteriler vekile verilecek primin niteliği hususunda her zaman net bir bilgiye sahip olamayabilir.

Yatırım vekaletinde kâr ile ilgili önemli olan diğer bir husus ise vekil sıfatıyla bankanın, müvekkilin onay vermesi durumunda kâr dengeleme ihtiyat fonu oluşturabilmesidir. Bu fonun işlevi, ortalama kâr oranının sürdürülmesine yardımcı olmaktır. Ayrıca yatırım faaliyetinin tasfiyesi halinde, vekâlet ücreti ve ihtiyat fonu için kesinti yapılan döneme ait prim dışında fondaki varlıkların tamamının müvekkile ait olduğu kabul edilmiştir. ${ }^{62}$ İhtiyat fonu uygulaması, müvekkilin hakkı ihlal edilmediği sürece fıkhi açıdan bir problem barındırmamaktadır. Bununla beraber, ihtiyat fonunun kullanım amacına dikkat etmek gerekir.

\subsubsection{Yatırım Vekaletinde Tazmin Sorumluluğu}

Yatırım vekaletinde tazmin sorumluluğu konusu, danışma kurulları nezdinde sıklıkla gündeme gelen önemli meselelerden biridir. Zira bu mesele, tarafların riski üstlenmesinde belirleyici olduğundan yapılan işlemin faizli işlem mesabesinde olup olmadığına karar vermede kilit rol oynamaktadır. Klasik fıkıh eserlerinde tazmin sorumluluğu ile ilgili verilen hüküm; vekilin, faaliyetleri esnasında kasıt ve kusuru bulunmadığı sürece tazminle sorumlu tutulamayacağ 1 yönündedir. ${ }^{63}$ Bununla beraber, katılım bankalarında uygulanan yatırım vekaletinde vekilin tazmin sorumluluğu meselesi bu teorik çerçeveden ayrılmakta ve vekil olarak bankanın müşterisine ödeyeceği tahmini kâr göz önüne alınarak değerlendirilmektedir.

59 Arsebük, Düreru'l-Hukkâm, 554; Semerkandî, Tuhfetü'l-Fukahâ, 235; Kâsânî, Bedâiu's-Sanâi', 434.

60 AAOIFI, Faizsiz Finans Standartları, 1088.

61 AAOIFI, Faizsiz Finans Standartları, 1096.

62 AAOIFI, Faizsiz Finans Standartları, 1089.

63 Arsebük, Düreru'l-hukkâm, 561. 
Yatırım vekaletinde banka, belirlenen tahmini kâr oranını müşteriye bildirir. Taraflar arasında vekalet sözleşmesi, bu tahmini kâr oranı üzerinden yapılır. Sözleşmede belirlenen bu oranın, vekil konumundaki bankaya her durumda tazmin sorumluluğu yükleyen bağlayıcı bir taahhüt niteliğinde olması ile banka açısından bağlayıcı olmayan bir ön bilgilendirme niteliğinde olması arasında fıkhi açıdan önemli bazı farklar bulunmaktadır. ${ }^{64}$ Burada her iki durum, uygulama ve bunun fikha yansıyan neticeleri açısından değerlendirilecektir.

Tahmini kârın tazmin sorumluluğu gerektiren bağlayıcı bir taahhüt niteliğinde olması durumunda vekil, yatırımların belli faaliyetlerde değerlendirileceğine ve bu faaliyetlerden belli bir oranda (örneğin \%10) kâr elde edileceğine dair müvekkiline karşı yükümlü olur. Daha fazla kâr edilmesi durumunda belirlenen oranın üzerindeki miktar, vekile prim olarak bırakılır. Anlaşılan oranın altında kâr edilmesi durumunda ise vekil, müvekkile karşı kusurlu davranmış kabul edilir ve eksik kalan miktarı tazminle sorumlu olur. $\mathrm{Bu}$ taahhüdün getirilmesinin temel nedeni, konvansiyonel bankaların mevduat sahiplerine belirli bir faiz oranında getiri sağlamasına benzer şekilde, katılım bankalarının müşteri tarafından elde edilecek getiriyi sabitleme isteğidir. ${ }^{65}$

Sözleşmeye bu nitelikte bir taahhüt eklemek fikhen caiz değildir. Çünkü böyle bir işlem, vekil konumundaki bankaya elindeki malların emanet hükmünde olmasını engelleyecek ek bir sorumluluk yüklemektedir. İslam hukukunda ise yalnızca müvekkilin getirdiği şartlara yahut toplum örfüne aykırı davranışı veya malın zayi olmasında kasıt, kusur, ihmalinin bulunması hallerinde vekilin zararı tazmin sorumluluğu bulunmaktadır. ${ }^{66}$ Bu bağlamda örneğin, satıma vekalette müvekkil vekilini, malı belli bir miktardan aşağı satmamakla yükümlü tutabilir. Vekil bu kayda bağlı kalmak durumundadır. Ancak yatırım vekaletinde genel itibariyle katılım bankasına mutlak vekaletle yetki verilmektedir. Netice itibariyle vekil konumundaki banka, yatırımda belirli araçların kullanılması şeklinde bir kayıtla sınırlandırılmayıp yatırım konusunda mutlak olarak yetkilendirilmiş ise, sözleşmede herhangi bir ek sorumluluğu re'sen üstlenmesi caiz değildir. ${ }^{67}$ İşlem mukayyed vekalet olarak değerlendirildiğinde ise belli oranda getiri sağlama kaydının vekil olan banka tarafından getirildiği görülmektedir. İşlem mukayyed vekalet sayılsa bile, ilgili kaydın vekilin kendisinden gelmesi hasebiyle problem barındırmaktadır.

64 Çakır, "Yatırım Vekâleti Uygulamalarında Kârın Tazmini Problemi", 34.

65 Halitoğlu, "Yatırım Araçlarının Fıkhi Niteliğii", 156.

66 Arsebük, Düreru'l-hukkâm, 561.

67 Çakır, "Yatırım Vekâleti Uygulamalarında Kârın Tazmini Problemi", 37. 
Kâr ve zarar ihtimali bulunan ticaret faaliyetinden sabit bir getiri garanti etmek, işin asıl sahibi olan müvekkile riskin yansıtılmaması anlamına gelmektedir. Bu durumda müvekkil, ticaretin riskini kendi açısından sıfırlamış olmaktadır. Vekil ise esasında doğası itibariyle riskli bir faaliyet olan ticarette riski üstlenerek vazifesi dahilinde olmayan bir sorumluluğu üzerine almış olmaktadır. Akdin gereklerinden olmayan bu tür taahhütlerin -zımnen de olsakabul edilmesi, ancak katılım bankalarının geleneksel bankacılık çizgisini takip etmek istemesiyle açıklanabilir. Bu durum, katılım bankalarını gerçekte sahip oldukları hüviyetlerini kaybetmeye mahkûm edebilir. ${ }^{68}$ AAOIFI'nin konuyla ilgili kararına göre, yatırım vekaletinde müvekkilin tahmini kârdan daha düşük miktarda kâr getirecek işlemlerin yapılmaması şeklinde koştuğu şart muteberdir. ${ }^{69}$

Tahmini kârın, tazmin yükümlülüğü gerektirmeyen bir ön bilgilendirme niteliğinde olmasında fikhi açıdan herhangi bir mahzur yoktur. Nitekim bu işlemde bankanın tahminen elde edeceği kâr miktarını müşteriye bildirmesinin herhangi bir bağlayıcılığı yoktur. Konu ile ilgili dikkat edilmesi gereken önemli noktalardan biri de şudur: Kârın tazminine yönelik herhangi bir taahhüt bulunmaması durumunda bile, söz konusu tazminin örf haline gelmemiş olması gerekmektedir. Diğer bir ifadeyle müşterilerin, tahmini kâr miktarını vade sonunda kesin olarak teslim alacaklarına dair bir beklenti veya inançlarının bulunmaması gerekir. Nitekim İslam hukuku açısından, toplumda teamül haline gelmiş bir husus sözleşmede açıkça belirtilmese bile şart koşulmuş sayılır. ${ }^{70} \mathrm{Bu}$ durumda da teoride bağlayıcı olmayan bir durum, örf sebebiyle gerekli ve bağlayıcı bir niteliğe bürünür. Taraflardan birine - yatırım vekaleti hususunda müşteriye - ek fayda sağlayan bir gerekliliğe itibar etmek, sözleşmeyi fıkhi açıdan geçersiz kılar. Netice itibariyle katılım bankalarının, toplumda ve müşteriler nezdinde tahmini kâr ile ilgili bir beklentinin oluşup oluşmadığı noktasında da dikkatli olmaları gerekmektedir. Böyle bir teamülün oluşması halinde, işlemleri revize etmeli yahut tamamen durdurmalıdırlar.

\section{Sonuç}

İslami bankaları özgün kılan en önemli özelliklerinden biri kâr zarar paylaşımına dayalı yapılarıdır. İdealde sadece fon toplarken değil finansman sağlarken de bu yöntemi takip etmeleri arzulanmaktadır. Ancak bu kuruluşlar operasyonel zorluklar, yasal düzenlemelerin kısıtlayıcı durumu, talep yetersizliği, güvenilir girişimci eksikliği gibi sayılabilecek -birçoğunda da haklılık payının olduğu- sebeplerle finansman tarafında kâr zarar paylaşımına dayalı

68 Halitoğlu, "Yatırım Araçlarının Fıkhi Niteliği", 159.

69 AAOIFI, Faizsiz Finans Standartları, 1090.

70 Heyet, Mecelletü'l-ahkâmi'l-'adliyye (Arambağ: Nur Muhammed Kârhane Ticaret Kütüb, t.y.), 21; Çakır, "Yatırım Vekâleti Uygulamalarında Kârın Tazmini Problemi”, 40. 
(mudârebe, müşâreke) yöntemlerini çok sınırlı kullanmakta ya da hiç kullanmamaktadır. Bununla birlikte fon toplama tarafında mudarebe hesapları ile bu özgün yönleri devam etmektedir. Ancak dünyadaki uygulamalarla paralel olarak Türkiye'deki katılım bankaları da 2018 yılından itibaren vekalete dayalı katılma hesaplarını yurt içindeki müşterilerine yönelik olarak kullanmaya başlamıştır.

Vekalete dayalı katılma hesaplarının fikhi ve uygulama açısından sakıncaları bulunmaktadır. Fıkhi açıdan sınırları zorlayan tarafı vekil sıfatıyla bankanın, müşterisine belirli bir tahmini kâr oranını sunmasıdır. Söz konusu tahmini kâr oranının garanti edilmediği ve gerçekleşen kârın bu orandan daha az olması durumunda tahmini kâr oranının müşteriye yansıtılmayacağı katılım bankaları tarafından ifade edilse bile, uygulamada -kâr dengeleme rezervlerinin de sayesinde- her durumda tahmini kârın müşteriye yansıtıldığı görülmektedir. Bu durum, İslam hukukundaki akitte taraflardan birine ek fayda sağlayıcı bir şart koşulmaması veya böyle bir durumun teamül haline gelmemesi gerektiği kuralına aykırılık teşkil etmektedir. Nitekim katılım bankasının, müşterisi ile üzerinde anlaştığı tahmini kârı sağlamadaki sürekliliği, müşteriler nezdinde bu oranın her durumda sağlandığı yönünde bir beklenti oluşturmakta ve zaman içinde uygulama bu yöne doğru kayabilmektedir. Günümüzde vekalete dayalı katılma hesaplarıyla ilgili yaşanan durum da bu savı teyit etmektedir. Katılım bankaları vekalet sözleşmesinde açıkça şart koşmasalar veya taahhüt etmeseler bile fiili olarak tahmini kârı sağlama konusunda gayret göstermektedirler. Müşterilerin beklentisi ve yerleşik bankacılık örfü de bu yöndedir. İslam hukukuna göre teamül olarak yerleşmiş bir husus, akitte şart koşulmuş gibidir. Beklenti ve teamülden kaynaklanan böyle bir gerekliliğe sözleşme içerisinde itibar etmek, taraflardan birine ek fayda sağlayacağı için caiz değildir. Ayrıca bu durum, işlemi sonuçları itibariyle konvansiyonel işlemlere yaklaştırmaktadır.

Ayrıca vekalet yatırım hesaplarının açılma gerekçesi ilerleyen dönemde katılım bankalarının "piyasa rekabeti" nedeniyle İslami finansın özüne uygun olmayan ya da üzerinde tam ittifak bulunmayan fikhen sakıncalı işlemleri yapmalarına neden olabilir. Söz konusu hesabın açılmasındaki, faizlerin arttığı ortamlarda getiri hassasiyeti yüksek olan müşterileri tutma amacı makul bir yaklaşım değildir. Çünkü arızi bir durum için katılım bankacılığının bel kemiğini oluşturan mudarebeye dayalı katılma hesaplarının yerini sabit bir tahmini kâr sunan vekalet hesaplarının alma riski bulunmaktadır. Ayrıca bu bakış açısı ile getiri hassasiyetine sahip müşterilere "tahmini kâr"ın altında bir getiri verilmesi ne kadar gerçekçidir? Böyle bir durumda katılım bankaları, varlık sebepleri ile çelişecektir. Bu risk ve endişe hem TKBB Danışma Kurulu'nun kararında hem de katılım bankaları tarafından yatırım vekaleti hesaplarına ilişkin neredeyse çok az bir bilgi sunulmasından da anlaşılmaktadır. 
Bu endişelerle birlikte yapılan düzenleme sonucunda vekalet yatırım hesaplarının nasıl uygulandığına ilişkin kamuoyu ile bilgi paylaşılması da şeffaflığın bir gereğidir. Aksi takdirde yatırım vekaleti üzerindeki soru işaretleri daha da artacaktır. Tüm bunların yanında böylesine yapısal bir değişiklik yerine, İslami finansın idealindeki kâr zarar prensibine uygun yeni metotlar çerçevesinde gayretler gösterilmesi gerekmektedir. Piyasa rekabeti, üzerinde ihtilaflar olan uygulamalara değil daha özgün yöntemlerin incelenmesine teşvik etmeli, bu çerçeve içerisinde çözümler bulunmalıdır. İslami finansın gelişimine katkıda bulunacak uygulamalar tasarlanırken, işlemin şeklî olarak fıkha uygunluğundan ziyade sonuçları itibariyle neyi temin ettiğine bakmak daha isabetli bir tutumdur. Aksi takdirde İslam ekonomisi disiplininin konvansiyonel sistem içinde erimesinin önüne geçmek mümkün olmayacaktır.

Bununla birlikte her ne kadar yatırım vekaleti hesaplarıyla ilgili sorunlar bulunsa da bu hesaplar, ilgili yönetmeliğin yasalaşma sürecinde izlenen yok açısından güzel bir uygulama sunmuştur. BDDK'nın TKBB Danışma Kurulu ile olan süreç içerisindeki diyalogu ve gelen değerlendirmelerin çoğunun düzenlemeye yansıtılması oldukça pozitif bir yaklaşımdır ve sektörün daha sağlam bir zeminde ilerlemesi için elzemdir. Aynı yaklaşımın İslami finansın diğer alanlarında da ilgili kamu kuruluşları tarafından gösterilmesi Türkiye'de İslami finansın daha doğru bir zeminde ilerlemesine katkı sunabilecektir.

\section{Kaynakça}

AAOIFI, Accounting and Auditing Organization for Islamic Financial Institutions. Faizsiz Finans Standartları. İstanbul: Türkiye Katılım Bankaları Birliği Yayınları, Yayin No: 10, 2018.

Albaraka Türk. Albaraka Türk 2011 Yılsonu Bağımsız Denetim Raporu (2011).

Albaraka Türk. Albaraka Türk 2013 Yılsonu Bağımsız Denetim Raporu (2013).

Albaraka Türk. Albaraka Türk 2019 Yılsonu Bağımsız Denetim Raporu (2019).

Albaraka Türk. "Yatırım Vekaleti Sözleşmesi”. Erişim 1 Nisan 2020. https://www.albaraka.com.tr/assets/tr/pdf/sozlesme-formlar/Yatirim-Vekaleti-Sozlesmesi.pdf

Albaraka Türk. "Yatırım Vekaleti Sözleşmesine Dayalı Katılma Hesabı". Erişim 12 Kasim 2020. https://www.albaraka.com.tr/assets/tr/pdf/yatirim-vekaleti-sozlesmesine-dayali-katilma-hesabi.pdf

Arsebük, Ali Haydar. Düreru'l-hukkâm şerhu Mecelleti'l-ahkâm. Beyrut: Dâru Âlemi'lKütüb, 2003.

Aybakan, Bilal. İslam Hukukunda Vekalet Sözleşmesi. İstanbul: Marmara Üniversitesi, Sosyal Bilimler Enstitüsü, Yüksek Lisans Tezi, 1990.

Aybakan, Bilal. "Vekalet". Türkiye Diyanet Vakfı İslam Ansiklopedisi. 43/1-6. İstanbul: Türkiye Diyanet Vakfı Yayınları, 2013.

Aysan, Ahmet F. vd. “Religiosity versus Rationality: Depositor Behavior in Islamic and Conventional Banks". Journal of Comparative Economics 46/1 (2018), 1-19. https://doi.org/10.1016/j.jce.2017.03.001 
BDDK, Bankacılık Düzenleme ve Denetleme Kurumu. BDDK Aylık Bülteni (Aralık 2019). https://www.bddk.org.tr/BultenAylik

Çakır, Mustafa. "Yatırım Vekâleti Uygulamalarında Kârın Tazmini Problemi”. Marife Dini Araştırmalar Dergisi 19/1 (2019), 23-44.

Dede, Kenan. Katılım Bankalarında Hazine Ürünleri ve Sermaye Piyasası Uygulamaları. İstanbul: TKBB Yayınları, 2017.

Emirates NBD. “Wakala Deposits". Erişim 6 Nisan 2020. https://www.emiratesnbd.com/en/personal-banking/accounts/savings-and-deposit-accounts/wakala-deposits/

Halitoğlu, İsmail. “Yatırım Araçlarının Fıkhi Niteliği”. Kilis 7 Aralık Üniversitesi İlahiyat Fakültesi Dergisi 5/8 (2018), 139-163.

Hattâb, Ebû Abdullâh Şemsüddîn. Mevâhibu'l-celil li şerhi Muhtasarı Halîl. Riyad: Dâru Âlemi'l-Kütüb, 2003.

Heyet. Mecelletü'l-ahkâmi'l-adliyye. Arambağ: Nur Muhammed Kârhane Ticaret Kütüb, t.y.

İbnü'l-Hümâm, Kemâlüddîn. Fethu'l-kadîr. Beyrut: Dâru'l-Kütübi'l-İlmiyye, 2003.

İKTİSAT, İslam İktisadı Araştırmaları Vakfı. “Katılım Bankacılığının Ruhuna el-Fatiha mı?". Erişim 18 Nisan 2020. https://www.iktisad.org.tr/katilim-bankaciligininruhuna-el-fatiha-mi/

İSEDAK, İslam İşbirliği Teşkilatı Ekonomik ve Ticari İşbirliği Daimi Komitesi. Diversification of Islamic Financial Instruments. Ankara, Türkiye: İSEDAK Koordinasyon Ofisi, 2017.

İslam İktisadı. "Katılım Bankaları ve Yatırım Vekaleti Hesapları". Erişim 15 Nisan 2020. http://islamiktisadi.net/index.php/2018/11/30/katilim-bankalari-ve-yatirim-vekaleti-hesaplari/

Ismail, Abdul Ghafar vd. “Tawarruq Time Deposit with Wakalah Principle: An Option That Triggers New Issues." International Journal of Islamic and Middle Eastern Finance and Management 9/3 (2016), 388-396.

Jaiz Bank Plc. "Jaiz Wakala Investment". Erişim 6 Nisan 2020. https://jaizbankplc.com/jaiz-product-and-services/private-banking/jaiz-wakala-investment/

Karaman, Hayrettin. "Teverruk". Yeni Şafak (2 Kasım 2018). https://www.yenisafak.com/yazarlar/hayrettinkaraman/teverruk-2047946

Kâsânî, Alâuddin. Bedâi'u's-sanâi' fì tertîbi'ş-şerâi'. Beyrut: Dâru'l-Kütübi'l-İlmiyye, 2003.

KFH Bahrain. "'Wakala' Investment Account”. Erişim 6 Nisan 2020. https://www.kfh.bh/bahrain/en/personal/investment/wakala-investment-account.html

Kuveyt Türk. Kuveyt Türk 2019 Faaliyet Raporu (2019).

Kuveyt Türk. "Katılma Hesabı: TL Katılma Hesapları”. Erişim 12 Kasım 2020. https://www.kuveytturk.com.tr/bireysel/hesaplar/katilma-hesaplari/katilmahesabi

Kuwait Finance House. "Wakalah Account". Erişim 12 Kasım 2020. https://www.kfh.com/en/home/Corporate-Banking/Accounts/Wakalah-Account.html\#termsandconditions 
Merğınânî, Burhâneddin. el-Hidâye fî şerhi Bidayetü'l-mübtedî. Pakistan: İdâretü'lKur'an ve'l-`Ulûmü'l-İslâmiyye, 1996.

Öztürk, Muhammet Kürşat. Vekalet Yönteminin İslami Finanstaki Yeri ve Türkiye İçin Bir Model Önerisi. İstanbul: İstanbul Sabahattin Zaim Üniversitesi, Sosyal Bilimler Enstitüsü, Doktora Tezi, 2019.

Mevduat ve Katılım Fonunun Kabulüne, Çekilmesine ve Zamanaşımına Uğrayan Mevduat, Katılım Fonu, Emanet ve Alacaklara İlişkin Usul ve Esaslar Hakkında Yönetmelik (5411. 60, 61, 62, 93). Resmî Gazete 30569 (18 Ekim 2018). Erişim 4 Nisan 2020. http://www.mevzuat.gov.tr/Metin.Aspx?MevzuatKod=7.5.10735\&MevzuatIliski=0\&sourceXmlSearch=mevduat ve katılım

Reuters UK. "Islamic Banks Launch Standard Wakala Agreement, Eye Uniformity Reuters". 2009. Erişim 6 Nisan 2020. https://uk.reuters.com/article/islamic-financial-wakala/islamic-banks-launch-standard-wakala-agreement-eye-uniformity-idUKKLR51488220091124

Semerkandî, Alâuddin. Tuhfetü'l-Fukahâ. Beyrut: Dâru'l-Kütübi'l-İlmiyye, 1984.

Şîrâzî, Ebû İshak. el-Mühezzeb fi fikhi'l-İmâm eş-Şâfi î. Dımaşk: Dâru'l-Kalem, 1992.

TKBB, Türkiye Katılım Bankaları Birliği Danışma Kurulu. “Karar No 2: Yatırım Vekaleti”. Erişim 6 Nisan 2020. https://tkbbdanismakurulu.org.tr/karar-no-2-yatirim-vekaleti/

Türkiye Finans. "Yatırım Vekaletine Dayalı Katılma Hesabı Sözleşmesi”. Erişim 6 Nisan 2020. https://www.turkiyefinans.com.tr/tr-tr/kobi/sozlesmeler-ve-formlar/SozlesmelerVeFormlarYururlukte/yatirim-vekaletine-dayali-katilma-hesabi-sozlesmesi.pdf

Türkiye Finans. “Dert Çözen Finansman”. Erişim 13 Kasım 2020. https://www.turkiyefinans.com.tr/tr-tr/bireysel/ihtiyac-finansmani/sayfalar/dert-cozen-finansman-destegi.aspx

Ziraat Katılım. Ziraat Katılım 2019 Yılsonu Bağımsız Denetim Raporu (2019). 


\section{Islamic Jurisprudence and Economic Analysis of the Wakāla Investment Accounts in Participation Banking \\ (Extended Abstract)}

Many types of contract are used in Islamic banking. Wakāla (agency) is one of these contracts and has been used extensively in different fields of Islamic finance recently. This trend in the global financial sector is also valid for Turkey. For many years, wakāla has been generally used as a complementary contract in the execution of the processes instead of forming the basis of such products. Therefore, wakāla is not considered as a fundamental instrument in participation banking (Islamic banking) transactions. Besides, while muḍāraba participation accounts, which are among the essential functions of participation banks (PBs), are used to raise funds by Islamic means and to provide income to investors based on profit-loss partnership, recently, wakāla investment accounts (WIAs) have been presented as a fund collection product. Accordingly, the PBs collect the funds according to the WIAs. Thus, as a wakäla contract, it has been transformed into a contract on which a detached product is built in the fund collection section, which is one of the most basic functions of PBs.

The new regulation in 2018 paved the way for fundraising of PBs based on WIAs. It has been noteworthy that the PBs offered a wakāla based product for the first time since they were collecting funds according to the mudāraba contract since the day they were established. Why such a breakdown has occurred is to be handled within the market dynamics in terms of implementation. However, some issues, such as an agreement on an expected fixed rate of profit, bring about discussions from a figh point of view. It is of great importance to examine and understand the WIAs, which may carry a similarity to interest (ribāwi) transactions, or which may lead to such a perception, from the point of view of the figh. Because the most essential feature of PBs is to being interest-free, and this vital principle is equally important on the funding side as well as on the financing side. In this context, the main purpose of the study is to deal with the functioning of the WIAs of the PBs in terms of market dynamics as well as their figh aspects, thus enabling them to be discussed and understood the issue from different dimensions.

To date, few studies have been conducted on the use of wakāla in Islamic finance in Turkey. Most of these studies have dealt with the subject in terms of jurisprudence and evaluated limitedly from the perspective of implementation. The significance of this study is to evaluate WIAs from both figh and implementation perspective by considering the application in global and domestic Islamic banking practices. It is expected that the paper will shed light on the steps to be taken in order to analyze the figh issues related to WIAs, to settle the subject on solid ground, and to continue with the improvement of the missing and problematic aspects of the practice. The study employs case 
analysis related to the functioning of WIAs in participation banking, and the thematic data analysis method was used about the figh issues on the WIAs. Within this framework, the relevant literature has been reviewed, and the case has been analyzed in detail by considering the current situation, basic approaches and problematic points. Besides, public data of PBs and available documents (annual reports and legal regulations) were used for analysis.

In the study, the problematic sides of the WIAs are revealed and discussed. Accordingly, the point that is pushing the boundaries in terms of Islamic jurisdiction is that the $\mathrm{PB}$, as a wakil (agent), offers a specific expected profit rate to its WIA customer. Even if it is stated by the PBs that the expected profit rate is not guaranteed and if the realized profit is less than this rate, the estimated profit rate will not be reflected the customer, in practice, it is seen that the estimated profit is accrued the customer in all cases due to the profit equalization reserve. This is in contradiction with the rule in Islamic law that there is no condition for additional benefits to one of the parties, or that such a situation should not become a custom. As a matter of fact, the continuity of the PBs in providing the expected profit that it has agreed with the WIA customer creates an expectation that this rate is achieved in all cases, and the application may shift in this direction in time. Today, the situation about WIAs confirms this argument. PBs are making efforts to make an estimated profit actually, even if they do not explicitly stipulate or undertake a proxy contract. This situation brings the transaction closer to conventional transactions.

Besides, the reason for opening WIAs may cause PBs to carry out legally objectionable transactions that do not comply with the essence of Islamic finance due to the "market competition" in the future. It is not a reasonable approach to open the account to keep the customers with high return sensitivity in environments where interest rates increase. Because for an incidental situation, there is the risk of substitution of participation accounts, which form the backbone of PBs, by WIAs that offer a fixed estimated profit. In such a case, PBs will contradict the raison d'être. This risk and concern can be understood from the fact that both the decision of the Advisory Board of Participation Banking Association of Turkey. Due to these concerns, disclosing information with the public by PBs regarding how WIAs are implemented is also a requirement of transparency. Otherwise, the question marks on these accounts will increase even more. Besides, market competition should encourage more authentic methods based on profit and loss sharing to be examined, rather than applications with conflicts, and solutions should be found within this framework. When designing a new product that is expected to contribute to the development of Islamic finance, it is more accurate to look at what the product provides in terms of its results rather than its formality. Otherwise, it will not be possible to prevent the Islamic economics discipline from melting in the conventional system. 